\title{
Geology and Uranium
}

\section{Occurrences in the}

\section{Miller Hill Area}

Carbon County

\section{Wyoming}

By JAMES D. VINE and GEORGE E. PRICHARD

CONTRIBUTIONS TO THE GEOLOGY OF URANIUM

GE OLOG I A L S UR V E Y B U L L E T I N 1074 - F

This report concerns work done on behalf of the U.S. Atomic Energy Commission and is published with the permission of the Commission

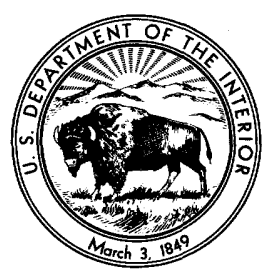


UNITED STATES DEPARTMENT OF THE INTERIOR

FRED A. SEATON, Secretary

\section{GEOLOGICAL SURVEY}

Thomas B. Nolan, Director 


\section{CONTENTS}

Introduction 202

Purpose and scope of the report 202

Location and geographic setting 202

Acknowledgments ... 202

Geologic setting - 204

Stratigraphy -

Precambrian rocks _... 205

Rocks of Paleozoic age-____ 205

Rocks of Triassic age-__- 205

Rocks of Jurassic age._._. 205

Rocks of Cretaceous age $\quad 206$

Rocks of Tertiary age $\quad 207$

North Park(?) formation $\quad 207$

Uncorrelated rocks of Tertiary age 212

Quaternary deposits _..._... 213

Structure

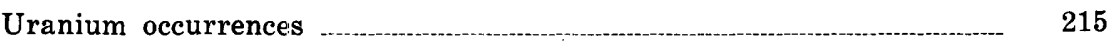

General description ..._- 215

Description of selected uranium Iocalities _.__ 217

Locality A-5

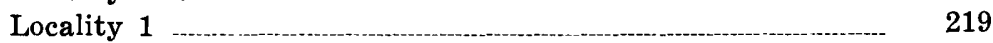

Locality 1A $\quad 220$

Localities 6, 7, and 16

Locality 9 -........- 221

Locality 17 _ 221

Locality 11 _._______ 221

Potential reserves .

Uranium content of natural water $\quad 222$

Spectographic data

Origin of uranium deposits 222

Hydrothermal deposition ........ 222

Concentration by living organisms 223

Chemical concentration by evaporation of saline solutions......-... 223

Concentration by redeposition of material leached from a disseminated source - 224

References cited _-_ 237

Index 


\section{ILLUSTRATIONS}

[Plates 14, 18, and 19 in pocket]

Plate 14. Geologic map of the Miller Hill area.

Page

15. Basal conglomerate of the North Park(?) formation..Facing 208

16. Typical outcrop and closeup view of the North Park(?) formation -

17. Photomicrographs of rock from the North Park(?) formation -

18. Isomadioactivity map of a part of the Miller Hill area.

19. Map showing sampled localities, test pits, and uranium content in a part of the Miller Hill area.

20. Photomicrographs of minerals from the North Park(?) formation Facing

FIgURE 10. Index map

11. Diagrammatic cross sections showing sequence of events during late Tertiary history of Miller Hill area

12. Map showing sampled localities

13. Sketch map of locality A-5

14. Sketch map of locality 1 .

TABLES

TABLE 1. Analyses and descriptions of rock samples from the Miller Hill area

2. Analyses and descriptions of water samples from the Miller Hill area

3. Analyses of 31 mineralized limestone samples from the Miller Hill area

4. Key to values for visual spectographic data listed in table 3

5. Approximate limit of detection for the elements determined by the visual spectographic method. 
CONTRIBUTIONS TO THE GEOLOGY OF URANIUM

\title{
GEOLOGY AND URANIUM OCGURRENCES IN THE MILLER HILL AREA, CARBON COUNTY, WYOMING
}

\author{
By James D. Vine and George E. Prichard
}

\begin{abstract}
Uranium occurs in the North Park(?) formation of Pliocene(?) age in the Miller Hill area, about 25 miles south of Rawlins, Carbon County, Wyo. The North Park (?) formation in the Miller Hill area is at least 800 feet thick and unconformably overlies all older rocks. It consists principally of waterworked fine-grained pyroclastic debris and detrital mineral grains and includes several fresh-water limestone beds.

Beds of brecciated silicified limestone 3 to 10 feet thick contain the principal concentrations of uranium. Lesser concentrations are found in calcareous sandstone and quartzite. Uranophane, $\mathrm{Ca}\left(\mathrm{UO}_{2}\right)_{2} \mathrm{Si}_{2} \mathrm{O}_{7} \cdot 6 \mathrm{H}_{2} \mathrm{O}$, the principal uranium mineral, has been deposited in vugs as fracture and surface coatings, and as a disseminated constituent of the rock. Uranium also occurs in quantities too small to be megascopically visible in dark-colored beds of chalcedony, limestone, and quartzite.

The uranium deposits in the Miller Hill area are thought to be a secondary concentration deposited from ground-water solutions that leached disseminated uranium from thick porous beds of tuffaceous sandstone in the North Park(?) formation. It is suggested that the mechanism for deposition was the reaction of silica- and uranium-rich ground water upon contact with limestone. The higher grade concentrations may represent further recent surficial enrichment of uranium due to evaporation of capillary moisture; however, uraniferous limestone that is continuously exposed to weathering for a relatively long period of time is eventually leached.

As much as 0.5 percent uranium is contained in grab samples, but only about 1,000 tons of rock is known to contain as much as 0.03 percent uranium. Visual spectrographic analyses of 31 samples of mineralized limestone are tabulated.
\end{abstract}




\section{INTRODUCTION}

\section{PURPOSE AND SCOPE OF THE REPORT}

An airborne radioactivity survey of the Miller Hill area (fig. 10) was reported by Meuschke and Moxham (1953) to indicate several anomalies in the vicinity of Miller Hill, and the results of a preliminary surface investigation of anomalies that had been located by airplane were reported by Love (1953). A later airborne radioactivity survey of the southern part of the area was reported by Henderson (1954). During the investigation covered by the present report an area of about 188 square miles was mapped in reconnaissance on aerial photographs, and about 2 square miles was mapped in detail in the area of highest radioactivity. About 45 new localities of above-normal radioactivity were found. The work was done by the U.S. Geological Survey on behalf of the Division of Raw Materials of the U.S. Atomic Energy Commission.

\section{LOCATION AND GEOGRAPHIC SETTING}

The Miller Hill area is in Carbon County, Wyo., about half way between Rawlins and the Colorado border (fig. 10). It is a dissected plateau that forms an apronlike area surrounding the north end of the Sierra Madre, the Wyoming portion of the Park Range. The area is transected by the Continental Divide, which separates the drainage of Sage Creek and associated tributaries of the North Platte River on the northeast from Savery Creek and other tributaries of the Little Snake River on the southwest. The plateau is formed on a surface of moderate relief at an elevation of 7,500 to 8,300 feet. Major streams flowing in V-shaped valleys are deeply incised on the plateau and flow onto the surrounding plains at elevations of 6,500 to 7,000 feet. The area is accessible in good weather through a network of secondary roads and trails. The main county road leads to Rawlins, about 20 miles to the north, and other roads provide access to Saratoga, about 22 miles to the east, and to Savery, about 24 miles to the south. Vegetation is sparse on the plains, though both conifer and deciduous trees grow in sheltered valleys and slopes.

\section{ACKNOWLEDGMENTS}

E. E. Murany and J. P. McDowell assisted during the fieldwork in 1953 and made many contributions to the study. Chemical, radiometric, and spectrographic analyses and mineralogic iden- 

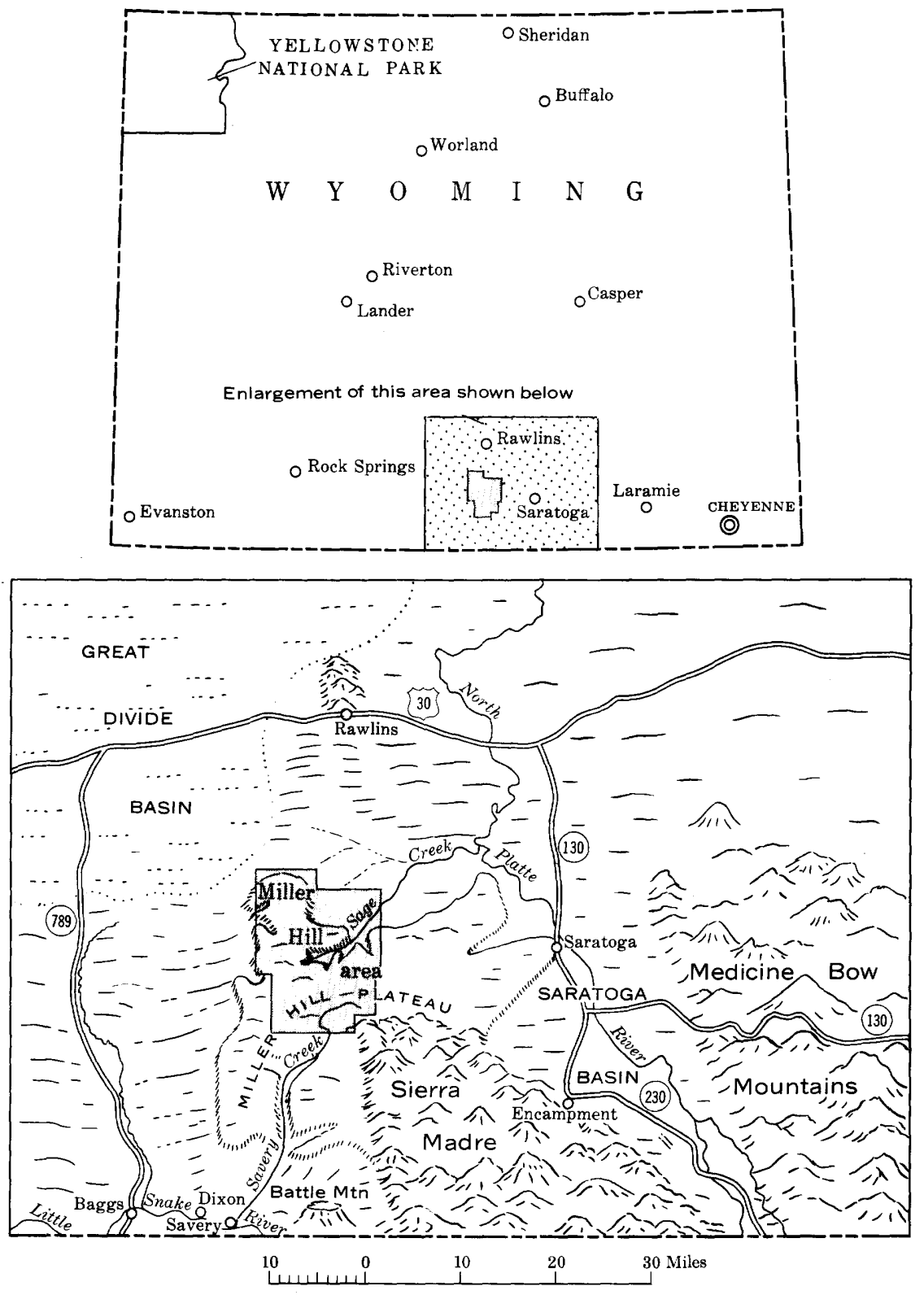

Figure 10.-Index map of the Miller Hill area, Carbon County, Wyo. 
tifications were made by personnel of the U.S. Geological Survey. Donald H. Johnson visited the field to assist with mineralogic identification.

\section{GEOLOGIC SETTING}

The high plateau that forms the major physiographic feature in the Miller Hill area is an erosion remnant of tuffaceous sandstone and limestone of late Tertiary age. This sequence of Tertiary rocks lies uncomformably on the folded rocks of Mesozoic age and older. (See pl. 14.) At the base of these Tertiary rocks is a moderately resistant conglomerate bed. In the northern part of the area this conglomerate forms a prominent escarpment at altitudes of 500 to 1,000 feet above the surrounding plains. (See pl. 15A.) Folded strata of Mesozoic age make up the middle and lower slopes below the escarpment as well as the lower plains and benchlands to the north and east. A prominent anticlinal fold in strata of Mesozoic age extends northward through the Hatfield oil field and terminates at the complexly faulted south end of the Rawlins uplift. To the east the high plateau merges with the Saratoga basin, where erosion has exposed Tertiary strata generally referred to the Browns Park formation of Miocene(?) age, and the North Park formation of questionable late Miocene or early Pliocene age (McGrew, 1951, 1953). Southeast of the mapped area, Precambrian rocks in the Sierra Madre rise above the onlapping rocks of late Tertiary age. To the south in the valley of the Little Snake River, also outside the area, rocks equivalent to the late Tertiary strata of the Miller Hill area seem to overlie similar but distinguishably different Tertiary strata. These underlying Tertiary rocks are thought to correlate with the Browns Park formation as mapped by Bradley (1945) at the south margin of the Washakie Basin west of Baggs, Wyo.

\section{STRATIGRAPHY}

Work during the 1953 field season was directed primarily toward finding and studying uranium deposits. As no areas of unusually high radioactivity were found in the pre-Tertiary rocks, very little time was devoted to study of these older rocks. The rocks of late Tertiary age are described in considerably greater detail because of their association with uranium mineralization in the area. The descriptions of the pre-Tertiary rocks are adapted from J. D. Love (1953), who summarized previous work, including data from a thesis written by Gene Del Mauro in 1953, and available at the University of Wyoming. 


\section{PRECAMBRIAN ROCKS}

The several types of Precambrian rocks exposed in the southeastern part of the area are undifferentiated on the geologic map (pl. 14). The rocks consist chiefly of gneiss and schist with smaller quantities of intrusive igneous rocks, pegmatites, and numerous veins of white quartz.

\section{ROCKS OF PALEOZOIC AGE}

Though not exposed in the mapped area, rocks of Paleozoic age are known from well data and are exposed on the west flank of the Sierra Madre south of the mapped area. These units are, from oldest to youngest: an unnamed sandstone unit of Cambrian age, 285 feet thick; the Madison limestone of Mississippian age, 80 feet; the Amsden formation and Tensleep sandstone of Pennsylvanian age, $600 \mathrm{feet}$; and unnamed limestone, dolomite, and sandy shale of Permian age, 225 feet thick.

\section{ROCKS OF TRIASSIC AGE}

Beds in the upper part of the Chugwater formation of Triassic age are the oldest rocks, other than Precambrian, which crop out in the area. The total thickness of Triassic rocks is probably between 800 and 1,100 feet. The characteristic red sandy shale and red siltstone of the Chugwater is well exposed in the Big Sage, Littlefield, and McKinney Creek areas. A conspicuous ochercolored zone about 10 feet thick near the top of the formation is exposed along Big Sage Creek, and a prominent pink to lavender sandstone zone is exposed in the Littlefield and McKinney Creek areas. The Alcova limestone member was not seen in the mapped area.

\section{ROCKS OF JURASSIC AGE}

Three formations of Jurassic age-the Nugget sandstone, the Sundance formation, and the Morrison formation-are present in the area. For convenience the Nugget sandstone and Sundance formation are not differentiated on the map (pl. 14), and the Morrison formation is mapped separately. The Nugget sandstone consists of cliff-forming grayish-yellow to white mediumgrained sandstone about 60 to 100 feet thick. Several springs in Sage Creek basin emerge from the Nugget sandstone. The Sundance formation overlying the Nugget sandstone consists of pale-red, pink, and gray sandstone and siltstone in the lower part 
and grayish yellow-green to yellowish-gray shale and sandstone containing abundant marine fossils in the upper part. The total thickness of the Sundance formation is about 135 feet. The Morrison formation consists of about 250 feet of interbedded gray to light varicolored shale and siltstone, nodular fresh-water limestone, and thin silty sandstone. It forms slopes that are commonly covered by talus and landslide material from sandstone beds in the overlying Cloverly formation.

\section{ROCKS OF CRETACEOUS AGE}

Six formations of Cretaceous age are exposed in the area and are mapped individually ( $\mathrm{pl} .14$ ).

The Cloverly is the oldest formation of Cretaceous age. Exposures consist chiefly of cliff-forming medium- to coarse-grained white to yellowish-gray clean quartz sandstone and chert-pebble conglomerate, which weather into large angular limonite-stained blocks. The sandstone is characterized by the reflection of sunlight from numerous crystal faces of quartz. Locally the sandstone beds are intercalated with black carbonaceous shale partings. The formation is 130 feet thick where exposed on Little Sage Creek.

The Thermopolis shale overlies the Cloverly formation and consists of about 100 feet of dark-gray to black marine shale in the lower part and black shale interbedded with thin beds of brown to gray ferruginous sandstone (the so-called Muddy sandstone) in the upper part. The unit is generally poorly exposed.

Overlying the Thermopolis shale is about 350 feet of Mowry shale, a hard black, gray-weathering siliceous shale which forms bare slopes paved with hard broken shale chips. Fossil fish scales are abundant in the formation.

The Frontier formation overlies the Mowry shale and consists of about 700 feet of gray to brown sandstone interbedded with gray to black shale and thin lenticular beds of chert-pebble conglomerate. Carbonaceous plant fragments are locally present in the sandstone.

The Niobrara formation overlies the Frontier formation and consists of nearly 1,200 feet of soft gray shale and yellowishgray calcareous shale.

The Steele shale overlies the Niobrara formation and consists mainly of gray sandy marine shale that becomes more sandy toward the top. The total thickness is about 3,600 feet but only the lower part is present in the mapped area. 


\section{ROCKS OF TERTIARY AGE}

\section{NORTH PARK(?) FORMATION}

The thick sequence of nearly flat lying nonfossiliferous predominantly arenaceous strata that lies unconformably on tilted and truncated rocks of Mesozoic, Paleozoic, and Precambrian age in the Miller Hill area is herein referred to as the North Park (?) formation. The name was originally applied to rocks of Tertiary age in North Park, Colo., by the King Survey in 1876. Arnold Hague and S. F. Emmons (1877) first described the rocks in the Miller Hill area, which they call the Savory Plateau region, as follows :

This region is principally covered by horizontal beds of the North Park Tertiary, which, as proved by exposures in the deeper cuts on its northern edge, overlie the upturned edges of Cretaceous and earlier beds, while the higher portions of the ridges are capped by remnants of the Wyoming conglomerate.

The North Park(?) formation underlies well over half the Miller Hill area (pl. 14). To the southeast it overlaps and thins out against the resistant rocks of Precambrian age that compose the Sierra Madre. Throughout the central part of the area the North Park(?) formation forms a plateau at altitudes ranging from about 7,500 to 8,300 feet. To the northeast, north, and northwest the limit of the North Park(?) formation is characterized by prominent escarpments (pl. 15A), particularly where erosion has cut deeply into underlying soft shale of Cretaceous age. These strata are as much as 800 feet thick locally, but the original thickness was probably greater because the present top is a surface of erosion.

The North Park(?) formation is divided into two members for convenience in mapping and description. The lower member is a basal conglomerate as much as 100 feet thick and the upper member is a sequence of fine- to medium-grained sandstone, tuff, and limestone beds as much as 700 feet thick.

The basal conglomerate member of the North Park(?) formation consists of a pebble-and-boulder conglomerate with boulders up to 3 feet across in a matrix of finer clastic material. The boulders include rocks composed of quartzite, limestone, granite, and gneiss, presumably derived from the Precambrian and Paleozoic rocks exposed in the Sierra Madre. White quartz pebbles and cobbles are a conspicuous constituent of the conglomerate in most areas. Black chert pebbles are also common, particularly in the northern part of the area. The basal conglomerate is typi- 
cally cross-stratified and composed of alternating lenses of coarse and relatively finer clastic materials. Medium- to large-scale cross-stratification, graded bedding, and irregular bedding (pls. $15 B$ and $15 C$ ) suggest that much of the material was deposited by rivers in flood stage. (Use of the terms for stratification and cross-stratification follow those suggested by McKee and Weir, 1953.)

The relatively high resistance to erosion of the basal conglomerate of the North Park(?) formation is the reason for the Miller Hill escarpment that rises abruptly above less resistant Cretaceous rocks in the northern part of the area. The escarpment is characterized by a zone of landslide debris at its base and by snowbanks that last into the late spring or early summer. The three diagrammatic sections of figure 11 show the probable relation of the base of the North Park(?) formation to the underlying strata.

Directly overlying and transitional with the basal conglomerate member is the upper member or main body of the North Park(?) formation. The upper member consists of sandstone, tuffaceous sandstone, tuff, and limestone beds. The bulk of the upper member is composed of very light gray to yellowish-gray laminated sandstone, generally horizontally stratified though cross-laminated locally (pl. 16). Sandstone beds contain detrital sand grains mixed in varying proportions with glass shards and clay minerals ( $\mathrm{pl}, 17 A$ ). Sand grains range in size from very fine to medium, and include angular, subrounded, and rounded forms. Small grains are generally more angular than large ones. Most of the grains appear to be quartz, though plagioclase feldspar, glass shards, ferromagnesian minerals, and opaque mineral grains are also present. Clayey tuff beds up to 4 feet thick that consist of glass shards about $0.1 \mathrm{~mm}$. in length in a matrix of clay minerals are interbedded with the sandstone.

The sandstone beds weather out in flaggy to massive units with varying degrees of induration ranging from well indurated to friable, though the bulk of the sandstone is slightly indurated. In the northern part of the area, notably along the southwest side of the drainage divide that extends from near the center of sec. 5, T. 17 N., R. 88 W., to near the center of sec. 13 of the same township, the sandstone beds are cemented with silica to form an extremely resistant quartzite unit. This cementation seems to be restricted to near the surface and is not apparent in the same strata where exposed in nearly vertical cliffs along the northeastward-facing escarpment. 


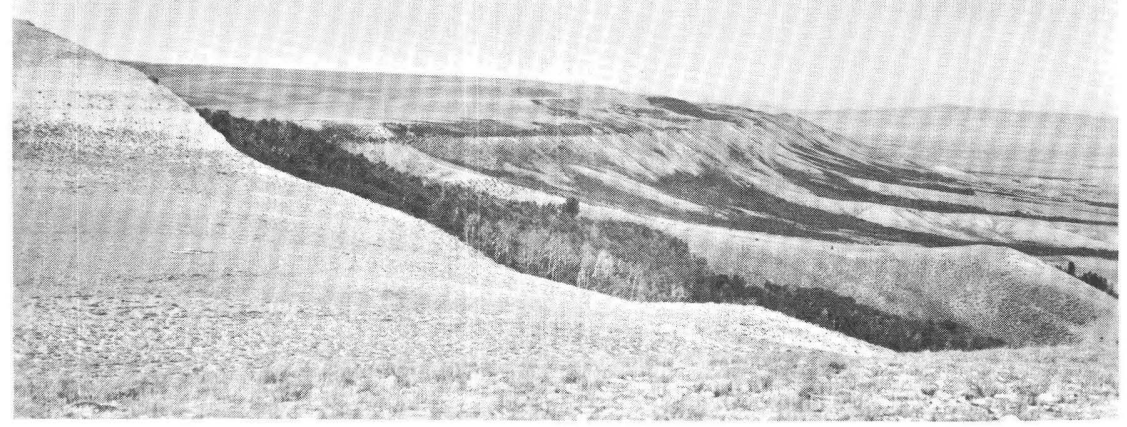

A. Escarpment formed by the basal conglomerate of the North Park(?) formation. Dark horizontal line of outcrop in upper-middle part of photograph indicates unconformity between rocks of Cretaceous and Tertiary age. View northwest from sec. 10, T. 17 N., R. 88 W.

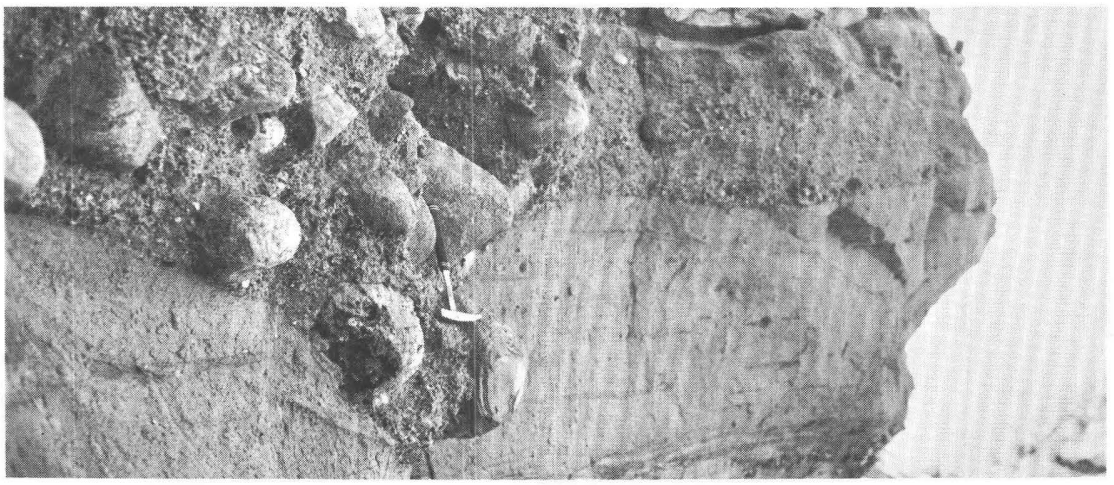

B. Local disconformity between two units of graded bedding within the basal conglomerate of the North Park(?) formation, sec. 7, T. 18 N., R. $88 \mathrm{~W}$.

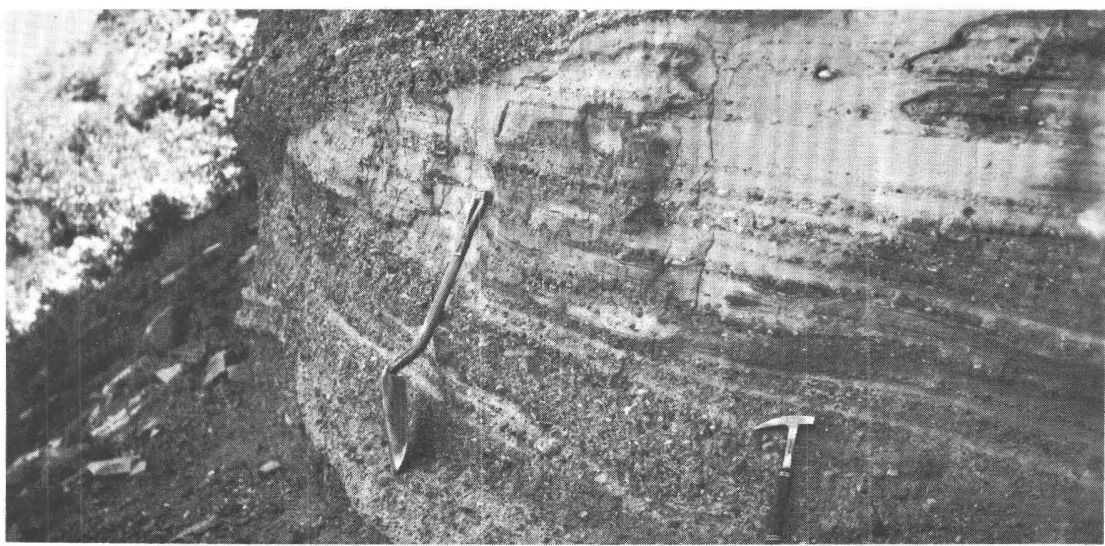

C. Cross-stratification and graded bedding within the basal conglomerate of the North Park(?) formation, sec. 7, T. 18 N., R. 88 W. 


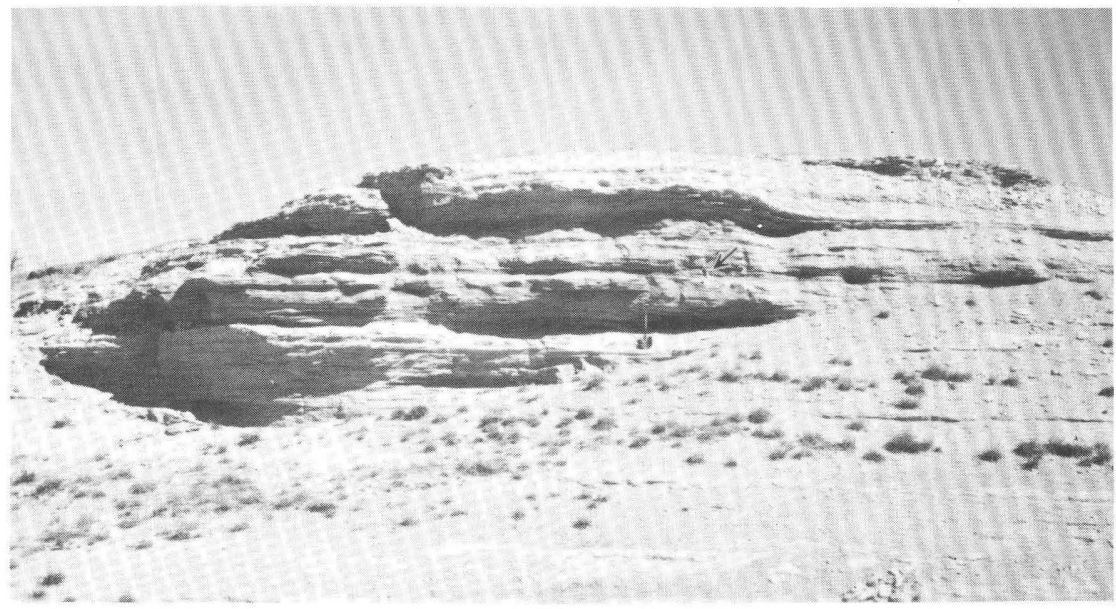

A. Typical outcrop of the North Park(?) formation of the Miller Hill area showing characteristic horizontal stratification. Arrow indicates position of hammer shown in $B$. View along main road in SE cor. sec. 31 , T. 17 N.. R. 87 W.

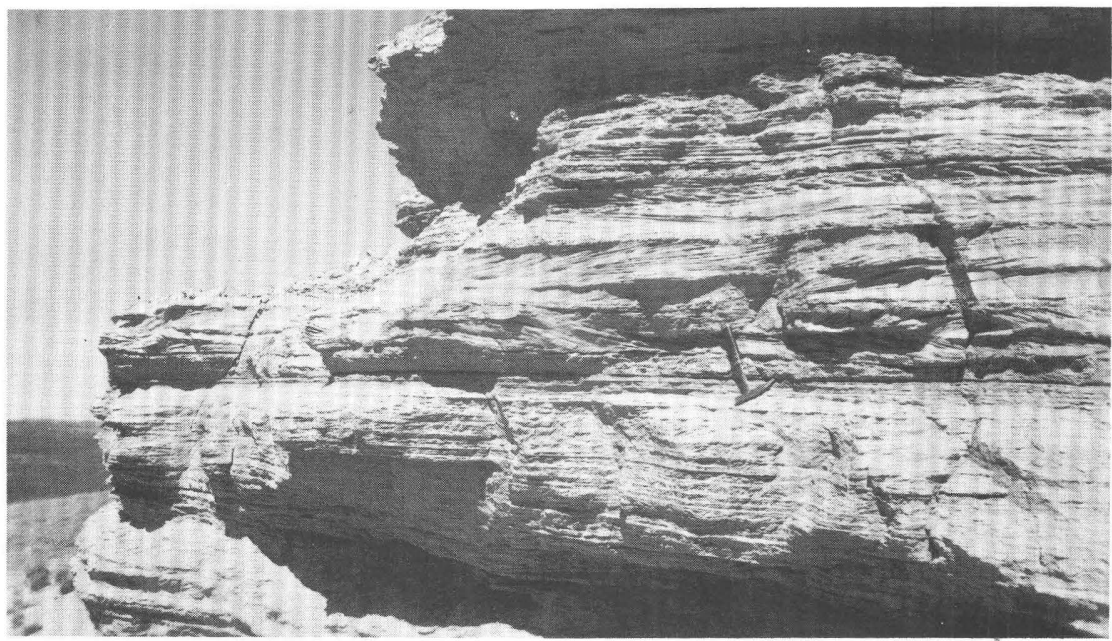

$B$. Closeup view of the same outcrop shown in $A$. Note the small-scale cross-lamination.

TYPICAL OUTCROP AND CLOSEUP VIEW OF THE NORTH PARK(?) FORMATION 


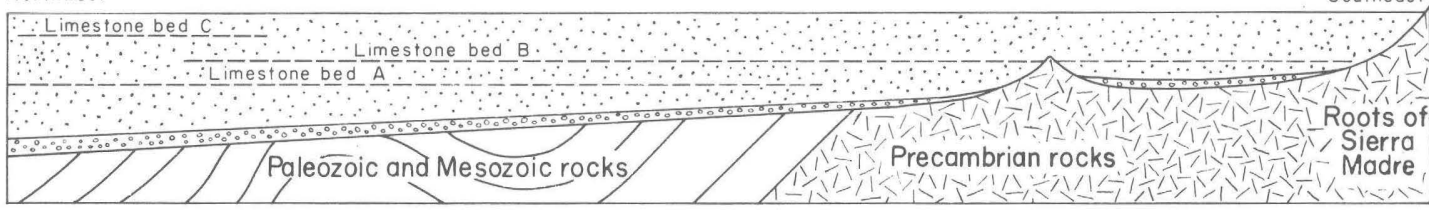

A. Deposition of the North Park(?) formation on a'gently tilted erosion surface

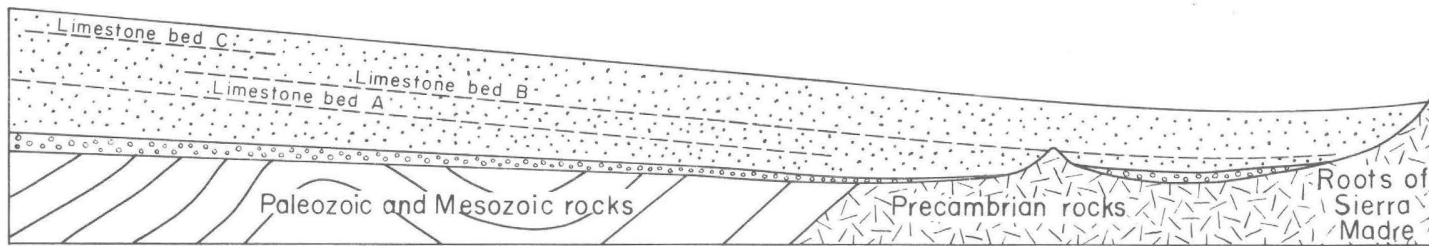

B. Uplift of basin area relative to the Sierra Madre

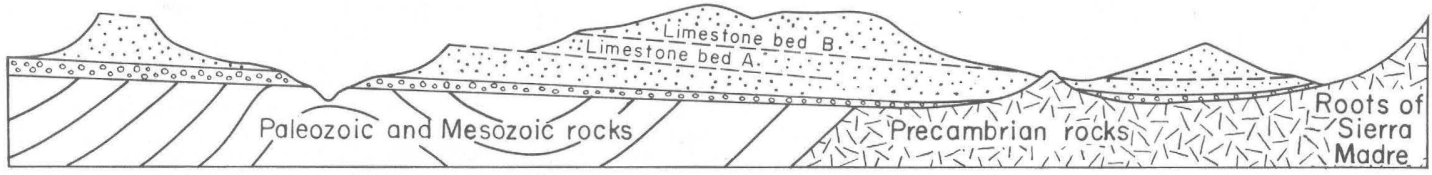

C.Erosion to present landform

FIGURE 11.-Diagramatic cross sections showing sequence of events during late Tertiary history, Miller Hill area, Carbon County, Wyo. (Vertical exaggeration about 5 times.) 
Locally, sandstone beds are cemented with calcium carbonate and form more resistant ledges than the noncalcareous sandstone beds. Calcareous sandstone beds grade into sandy limestone beds, and they, in turn, grade into beds of dense limestone. Limestone beds are locally brecciated and partially replaced by chalcedony (pl. 17B). Most of the uranium occurrences, are associated with silicified limestone.

In the area drained by Big Sage Creek and Little Sage Creek, two locally radioactive limestone beds designated bed $\mathrm{A}$ and bed B were mapped ( $\mathrm{pl} .14$ ). In the area southwest of the Continental Divide the lower two of three limestone beds designated bed $\mathrm{A}($ ?), bed $\mathrm{B}($ ?), and bed $\mathrm{C}($ ?) are tentatively correlated with bed $\mathrm{A}$ and bed $\mathrm{B}$ north of the divide. The two main limestone beds, $\mathrm{A}$ and $\mathrm{B}$, and the intervening strata occupy a stratigraphic zone about 135 to 150 feet thick and contain most of the abnormally radioactive rocks found in the Miller Hill area. Though this stratigraphic zone is thought to have a fairly uniform thickness, the interval between this zone and the basal conglomerate is thought to range from zero near the Sierra Madre to about 275 feet near the SE. cor. T. 17 N., R. 88 W., and as much as 400 feet about 10 miles northwest of the moutains.

Rocks mapped as the North Park(?) formation in the Milier Hill area have yielded no fossils useful in determining the age and correlation of the strata. For this reason various names and correlations have been suggested, beginning with the King Survey (King, 1876; Hague and Emmons, 1877), which used the name North Park Tertiary. Ball and Stebinger (1910) preferred to use the name Bishop conglomerate but suggested that it might be the westward continuation of rocks that Veatch (1907) mapped as North Park Tertiary in the coal fields of east-central Carbon County, Wyo. M. R. Campbell and others (1925) also show these rocks as the Bishop conglomerate of Pliocene and Miocene age. In a description of the Tertiary stratigraphy of the Saratoga basin, McGrew (1951) recognized two units based on faunal differences, which he designates from oldest to youngest the Browns Park and North Park formations respectively. In describing the Browns Park he states that

To the west it extends around the north end of the Sierra Madre Mountains and from there southward where it approaches and may even be continuous with the Browns Park near Craig, Colorado.

The use of the name Browns Park formation for rocks in the Miller Hill area has been followed more recently by Love (1953), Del Mauro (see p. 204), and Love, Weitz, and Hose (1955). 


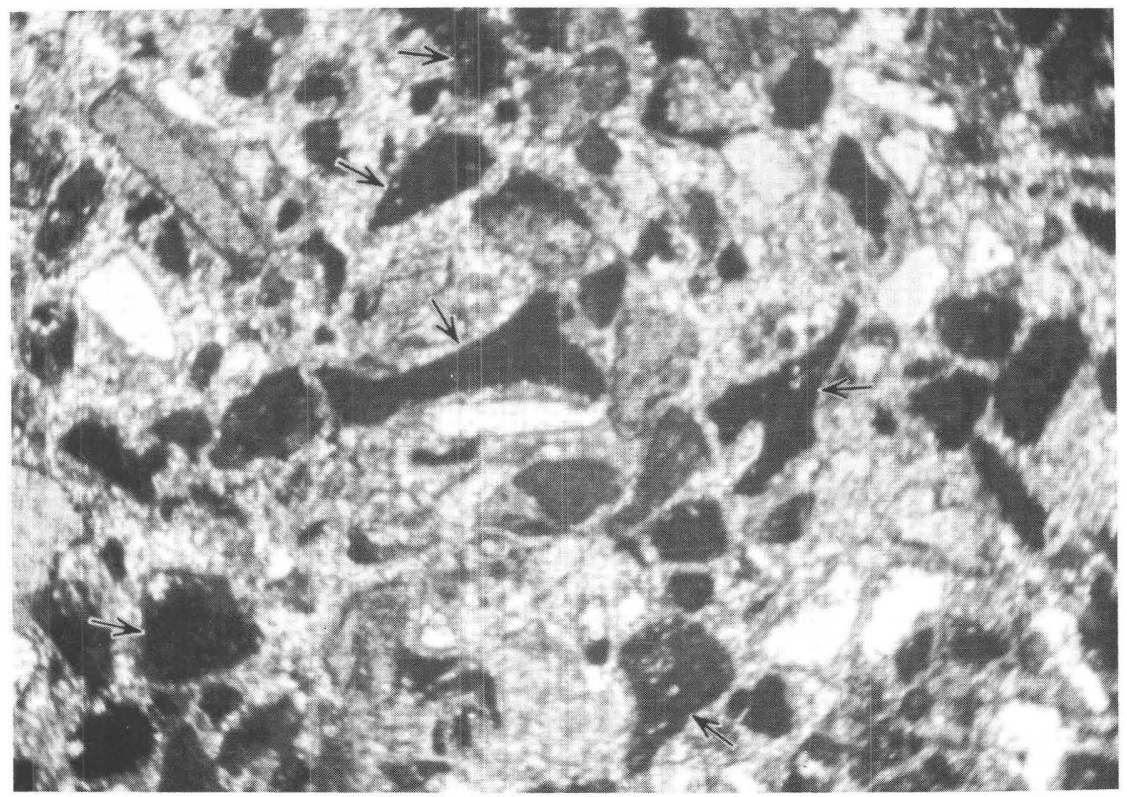

A. Photomicrograph of sandstone from the North Park(?) formation of the Miller Hill area. Arrows indicate typical glass shards. Magnification: $\times 80$. Crossed nicols.

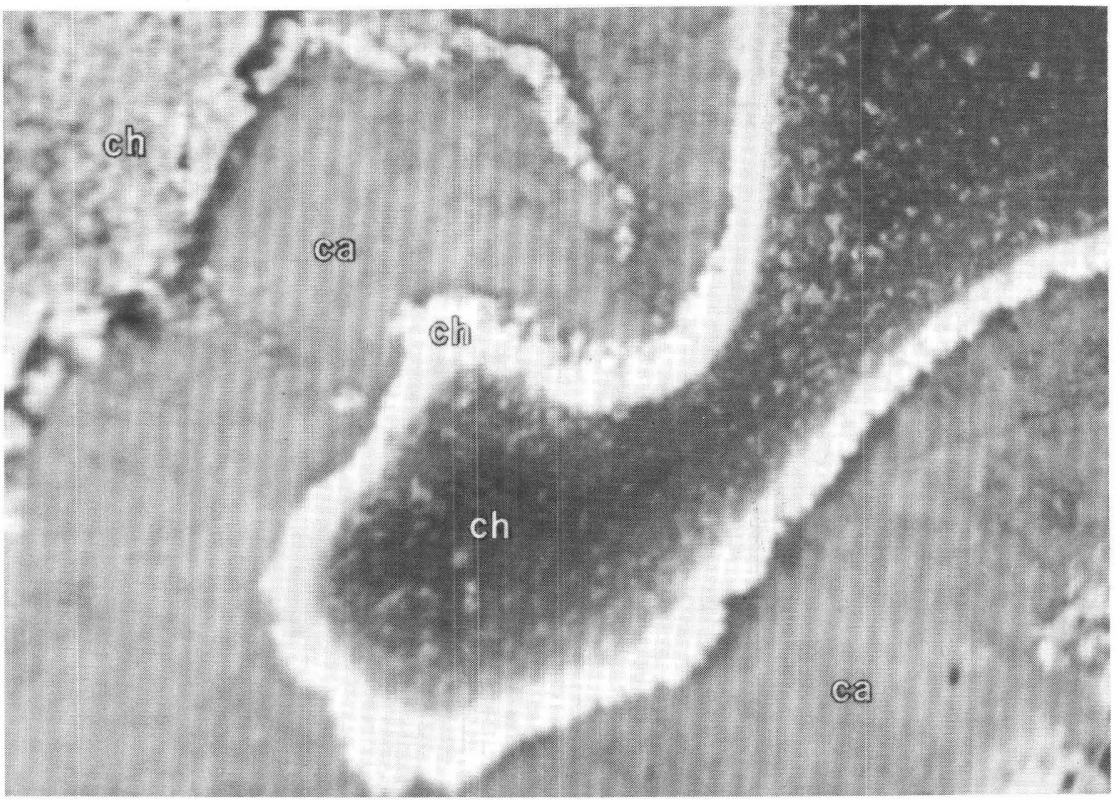

B. Photomicrograph of siliceous limestone from the North Park(?) formation of the Miller Hill area. Explanation: $c a$, calcium carbonate; $c h$, chalcedony. Magnification: $\times 16$. Ordinary light. 


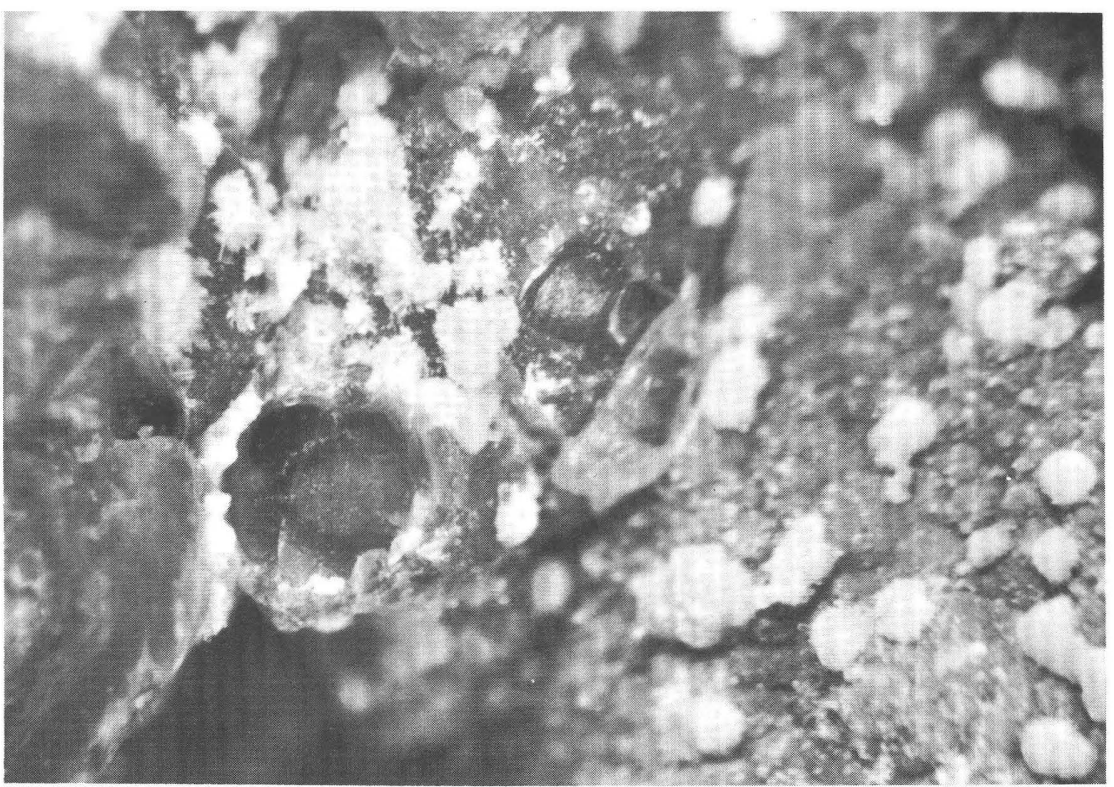

A. Photomicrograph of radiating crystal aggregates of uranophane occurring in opal-lined vug in brecciated limestone from locality $\mathrm{A}-5$. Magnification $: \times 16$. Ordinary light.

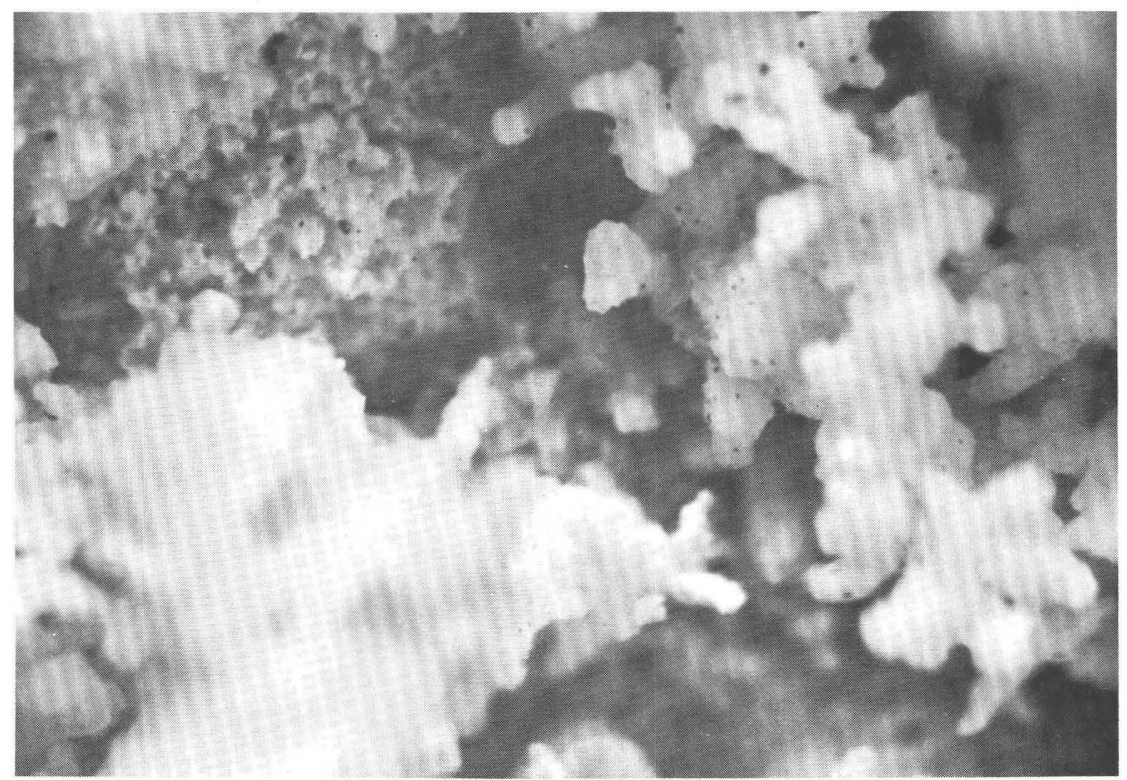

B. Photomicrograph of fluorescent travertinelike aggregate of uranophane, opal, and calcite from locality A-5. Magnification: $\times 16$. Ultraviolet light. 
During a reconnaissance investigation of uranium occurrences in the Saratoga area, Stephens and Bergin (1959) experienced difficulty in distinguishing the Browns Park formation from the North Park formation on the basis of lithologic characteristics. Rocks in the Miller Hill area are similar in many respects to rocks in both the Browns Park formation and the North Park formation in the Saratoga area. In the absence of faunal evidence, detailed stratigraphic and petrographic studies would be required to make correlations between the two areas. The interval of about 10 miles between the area near Saratoga investigated by Stephens and Bergin and the area investigated for the present report is characterized by prominent high-angle faulting, the displacement of which would have to be determined before it would be possible to trace rock units from the Saratoga basin into the Miller Hill area. However, at least two distinct major lithologic units seem to be represented by the rocks within the area that McGrew (1951) indicated as underlain by Browns Park; one unit extends southward from the Miller Hill area to Browns Hill and Green Ridge (T. 14 N., Rs. 88 and 89 W.) and the other extends southward from there to the Little Snake River. (See the Savery 30-minute topographic quadrangle sheet.)

The rocks to the south have been mapped by G. E. Prichard and W. A. Chisholm (written communication) and are thought to be equivalent to rocks in the Poison basin area near Baggs, which have been correlated with the Browns Park formation of Miocene(?) age (Bradley, 1945).

The Browns Park formation north of the Little Snake River near Dixon and Savery can be distinguished from rocks in the Miller Hill area by the fact that it is more friable and is characterized by medium- to large-scale trough-type cross-stratification. The Browns Park near Dixon and Savery is characteristically fine- to medium-grained sand in a fine-grained matrix of angular glass fragments. Clay-sized material, which is common in the sandstone beds in the Miller Hill area, is not so abundant. The basal conglomerate of the Browns Park formation lies below the level of the Little Snake River (about 6,400 ft. alt.) near Dixon but rises to an altitude of about 7,400 feet about 10 miles northeast of Dixon, where it forms the south escarpment of the canyon of Loco Spring Creek in sec. 4, T. 13 N., R. 89 W. At this point the tilted basal conglomerate of Browns Park is overlain by the nearly horizontal basal conglomerate of the North Park(?) formation along a spur of North Park that extends southward from Browns Hill into the NW. cor. T. 13 N., R. 89 W. This apparent 
unconformable relation between two distinctly different lithologic units, and the correlation of the older of these two units with the Browns Park formation, are the chief reasons for reverting to the name North Park for the rocks in the Miller Hill area. The question mark is used after the name "North Park(?)" in order to indicate the uncertainty of the correlation.

The age of the North Park formation has been the subject of controversy for some time. In several recent publications (McGrew, 1951; Love, Weitz, and Hose, 1955) the North Park has been designated as Pliocene in age. However, McGrew (1953) shows that the fauna from the North Park formation in the Saratoga area is equivalent to the Barstow formation of California, in accordance with Wood and others (1941), who consider the Barstovian to be latest Miocene. McGrew therefore calls the North Park latest Miocene in age. The designation used in this report is North Park(?) formation of Pliocene(?) age, using the query following both the age and name designations to show the uncertain correlation of the rocks in the Miller Hill area with the North Park formation and the uncertain age of the North Park formation.

\section{UNCORRELATED ROCKS OF TERTIARY AGE}

In the southeastern part of the area mapped, adjacent to the west flank of the Sierra Madre, and in the southern part of the Savery quadrangle, beyond the mapped area, several exposures of Tertiary strata differ so markedly from those described above, that additional formational units may be present. Adjacent to a projecting spur of Precambrian rocks in the SE. cor. T. 16 N., R. 88 W., is a conglomerate-capped hill which is higher than any of the surrounding Tertiary strata. The conglomerate, at least 100 feet thick, is composed of deeply weathered limonitestained Precambrian boulders. It is in fault contact with rocks of the North Park(?) formation of the Miller Hill area as well as with Precambrian rocks and is interpreted to be a conglomerate unit that is younger than the North Park(?) that has been downfaulted. A similar conglomerate unit has been described by Stephens and Bergin (1959) in an area about 7 miles west of Saratoga. Still farther south, just beyond the limits of the area mapped, on East Fork and Dirtyman Fork there are several exposures of coarse clastic material that appears to be reworked sandstone from the North Park(?) formation of the Miller Hill area mixed with coarse detritus from the Precambrian rocks exposed in the Sierra Madre. The relation between these rocks 
and the typical North Park(?) formation of the Miller Hill area is not clear. However, many hills adjacent to the Sierra Madre are covered by a mantle of soil and boulders which is probably an incipient pediment deposit formed during Pleistocene or Recent time, and this heterogeneous deposit may be a dissected pediment deposit.

\section{QUATERNARY DEPOSITS}

Pleistocene and Recent deposits in the area include alluvium, colluvium, landslide material, terrace gravel, and pediment gravel. Alluvium is confined to small areas along the valley bottoms of major streams. Colluvium has been mapped where steep valley slopes are mantled by recent debris which does not have the jumbled character of landslide material. Landslide material covers the lower slopes of nearly the entire northward- and eastward-facing escarpment of the North Park(?) formation of the Miller Hill area. Landslide material also occupies a large area in the lower valley of Big Sage Creek. In these areas the material consists of locally derived debris from steep slopes. Terrace gravel occurs adjacent to streams near the mountains and on interstream divides away from the mountains. Pediment deposits consisting of a thin mantle of gravel covering slopes of low gradient are found adjacent to the Precambrian rocks of the Sierra Madre.

\section{STRUCTURE}

Several periods of structural deformation are recorded in the rocks of the Miller Hill area. The earliest of these involved only the Precambrian rocks, as evidenced by steeply dipping quartzite beds. Sedimentary features in the rocks of Paleozoic and Mesozoic age, including unconformities, and coarse clastic rocks indicate minor fluctuations in the earth's crust. Laramide deformation, which affected rocks of Eocene age and older, uplifted the Precambrian rocks of the Sierra Madre and formed several large folds involving strata of Mesozoic age and older in the Miller Hill area. Del Mauro (see p. 204) describes the pre-Tertiary structure of the area and shows the Miller Hill anticline, trending northeastward through the NE. cor. T. 17 N., R. 89 W., to be a major structural feature with a closure of several hundred feet. This anticline, as well as several lesser structural features, has been tested for oil and gas without notable success.

No Eocene or Oligocene rocks are present in the Miller Hill area to record early Tertiary history. In the southern part of the 
Savery quadrangle the Browns Park formation of Miocene(?) age overlies all older rocks with marked angular unconformity, so it may be assumed that there was a period of uplift and erosion before deposition of the Browns Park. As an unconformable relation apparently exists between the North Park(?) formation and the underlying Browns Park formation, there must also have been a period of uplift and erosion after the Browns Park and before deposition of the North Park. The pedimentlike surface upon which was deposited the North Park(?) formation of the Miller Hill area must have formed during this brief time. Regional uplift and normal faulting, probably in late Pliocene or Pleistocene time, caused the North Park(?) formation to be tilted gently toward the Sierre Madre (fig. 11).

Thus, the Miller Hill area is a high plateau formed from an erosion remnant of upper Tertiary rocks that dip $2^{\circ}-3^{\circ} \mathrm{S}$. or SE. toward the Sierra Madre. Locally these Tertiary rocks are broken by high-angle faults with a displacement of 25 to 50 feet and possibly more.

Where erosion has removed the mantle of Tertiary rocks, folds related to the Laramide orogeny are revealed in the older rocks. These include the northeastward-trending Miller Hill anticline exposed along Littlefield and McKinney Creeks in the northern part of T. 17 N., R. 89 W. Rocks as old as the Chugwater formation of Triassic age crop out below the North Park(?) formation in the valley of Littlefield Creek. A syncline trending parallel to the Miller Hill anticline and about $21 / 2$ miles to the southeast brings the Niobrara formation directly below the escarpment of the North Park(?) in secs. 3 and 4, T. 17 N., R. 88 W. The northeastward-plunging nose of another anticline, as indicated by the outcrop pattern of the Mowry and Frontier formations, is visible north of Middlewood Hill. The exposures of northwestward-dipping Triassic and Jurassic rocks in the Sage Creek basin probably represent the northwest flank of the same anticlinal feature, though the surface trace of the crestline is not reflected in the structure of the overlying North Park(?) formation.

A number of high-angle faults, each with only a few feet displacement, are exposed near the contact of the Niobrara formation and the Steele shale in the northeastern part of the area. The age of these faults might normally be considered as Laramide because they displace rocks of Cretaceous age, but elsewhere, as in sec. 18, T. 17 N., R. 87 W., and along Littlefield Creek, similar faults are exposed that displace both rocks of Mesozoic 
age and the North Park(?) formation, indicating that movement along many of the faults was much more recent.

\section{URANIUM OCCURRENCES}

\section{GENERAL DESCRIPTION}

Uranium is erratically distributed throughout parts of the North Park(?) formation in the Miller Hill area. It is most abundant in those beds that are both calcareous and siliceous, though small amounts are also present in sandstone beds, particularly where limonite staining is apparent. The yellow uranium mineral uranophane, $\mathrm{Ca}\left(\mathrm{UO}_{2}\right)_{2} \mathrm{Si}_{2} 0_{7} \cdot 6 \mathrm{H}_{2} 0$, occurs as fracture coatings and vug fillings in brecciated and silicified beds of limestone and sandy limestone. Some small pellets of sandstone enclosed in the limestone contain disseminated uranophane. Uranophane also occurs with calcite and opal in secondary travertinelike coatings on the underside of broken limestone fragments. No discrete uranium minerals have been identified from much of the limestone, chalcedony, and sandstone in the North Park(?) formation that contains less than 0.1 percent uranium.

The locations of sampled localities are shown on figure 12. An isoradioactivity map (pl. 18) and a locality map (pl. 19) were prepared of several square miles in which most of the more promising areas of high radioactivity occur. Analyses of rock samples are listed in table 1 . The majority of the radioactivity anomalies are found in one or the other of two limestone beds, designated bed $\mathrm{A}$ and bed $\mathrm{B}$, or in the rocks between them; in the area containing most of the occurrences of uranium, these two beds are about 275 feet and 410 feet, respectively, above the basal conglomerate. Locally, uranium also occurs in younger or older zones, as in the Sage Creek basin (localities 44, 45, and 46) where uranium occurs in strata 50 to 100 feet above the basal conglomerate. No anomalous radioactivity was detected in rocks older than the North Park(?) formation.

Uranophane also has been discovered in the Ketchum Buttes area, about 2 miles southwest of the report area. This deposit occurs in claystone and sandstone probably less than 200 feet above the basal conglomerate of the North Park(?) formation.

Silicified, brecciated limestone containing more than 0.1 percent uranium in grab samples was collected from seven localities in secs. 25,35 , and 36, T. 17 N., R. $88 \mathrm{~W}$. To test the continuity at depth and the extent of uranium mineralization, eight pits were dug (pl. 19). Channel samples from these pits, which 


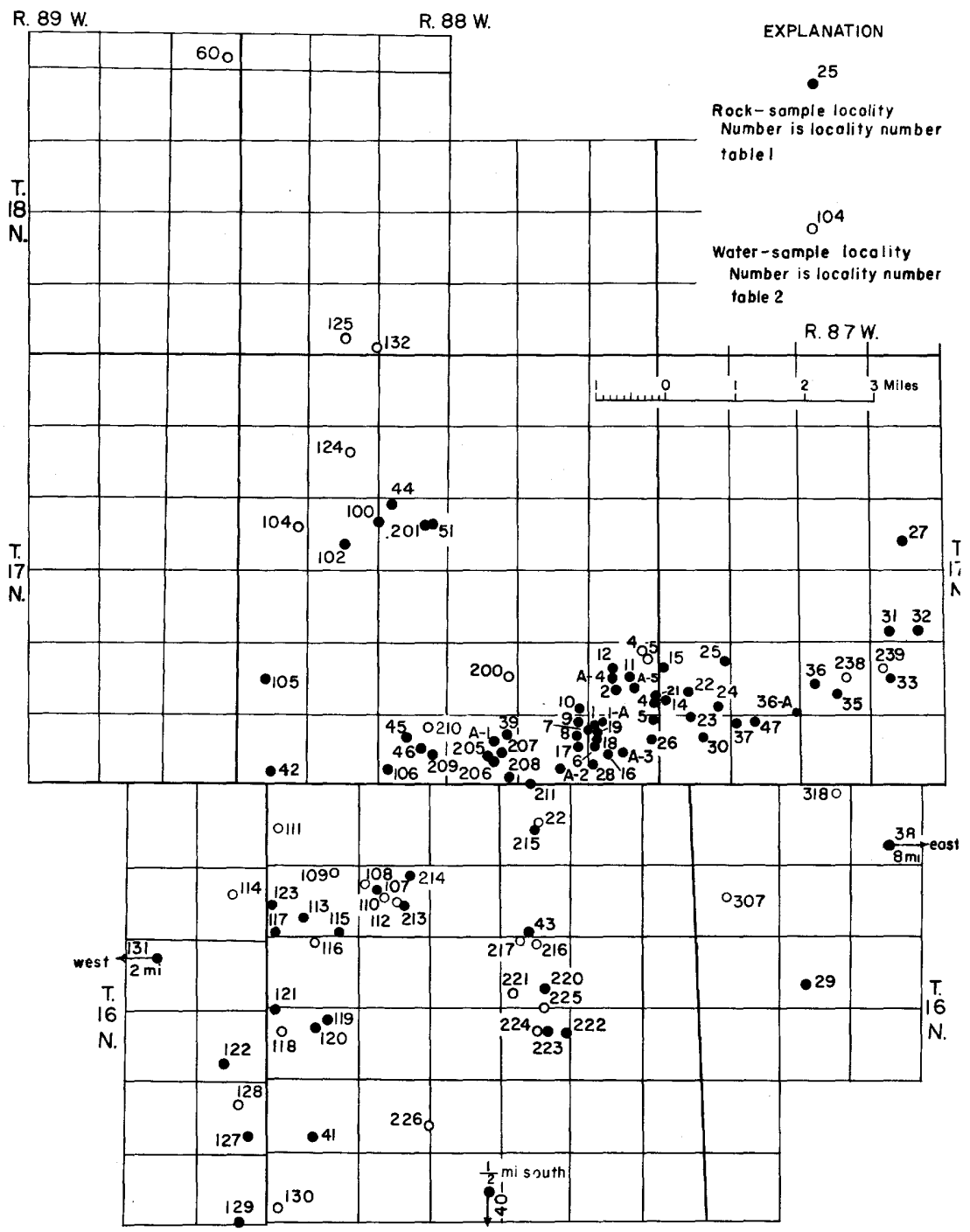

Figura 12.-Map showing sampled localities, Miller Hill area, Carbon County, Wyo.

were 4 to 8 feet deep, indicate that the uranium content is highest at or near the top of the bed and decreases abruptly downward. (See analyses of rock samples in table 1.) Equivalent uranium shows a similar vertical distribution but is generally higher than the uranium content at the top of the bed and less than or equal to the uranium content at the bottom of the bed.

A certain range of uranium content is fairly characteristic of the various rock types in the North Park(?) formation. An average of about 0.01 to 0.02 percent uranium is found in small 
lenses and irregular masses of dark-gray or brown chert and chalcedony commonly associated with limestone beds. A maximum of about 0.01 percent uranium is found in limonite-stained sandstone, quartzite, and calcareous sandstone. Up to about 0.1 percent uranium is contained in brecciated and recemented limestone where the recementation of the limestone is partly accomplished by minutely disseminated brown chalcedony and small blebs of light-gray chert. Thin greenish films of fluorescent uranophane are present as fracture coatings in this type of rock. The highest uranium content, up to about 0.5 percent, is found in brecciated and partly silicified limestone where recementation is incomplete. Microcrystalline aggregates of bright-yellow uranophane crystals associated with colloform opal are found in vugs in this type of rock (pl. 20A); the uranophane does not fluoresce. More commonly, however, vugs are lined with a palegreen dendritic mineral aggregate composed of an intimate intergrowth of calcite, opal, and uranophane (pl. 20B) that fluoresces yellow green. The pale-green intergrowths of calcite, opal, and uranophane grade imperceptibly into whitish intergrowths that fluoresce yellow green but probably contain less uranophane. The whitish intergrowths are found both in vugs and as travertinelike coatings on the underside of limestone fragments.

\section{DESCRIPTION OF SELECTED URANIUM LOCALITIES}

From the many localities of uraniferous rocks in the Miller Hill area the following nine are described in more detail: A-5, $1,1 \mathrm{~A}, 6,7,9,11,16$, and 17. These include all the localities that are highly radioactive, and together they provide enough detail to define the habit of uranium occurrences in this area. These localities are found in secs. 25,35 , and 36, T. 17 N., R. 88 W.

\section{LOCALITY A-5}

Locality A-5 (fig. 13) was discovered by aerial radioactivity survey in October 1952 by Meuschke and Moxham (1953) and was referred to as anomaly 47-16.6 on their preliminary map. At least 7,500 square feet of the exposed surface of limestone bed $A$ is moderately to highly radioactive in this area. Shallow trenches, designated $A$ to $G$ (fig. 13), were excavated along joints in the limestone and mapped in detail by Atomic Energy Commission personnel (J. P. Hadfield in charge). Pits designated 1 and 2 were later excavated into the massive limestone to depths 

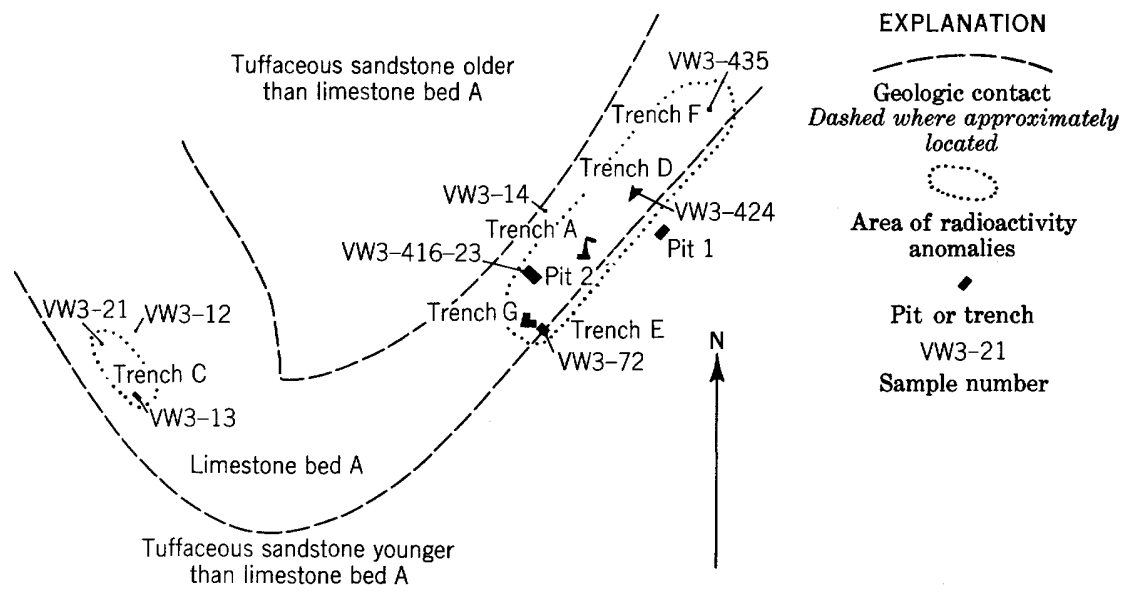

Sketch map compiled from planetable data

50

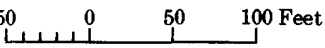

FraUru 13.-Sketch map of locality A-5 showing location of radioactivity anomalies and pits from which samples were collected for analysis, sec. 25, T. 17 N., R. 88 W., Carbon County, Wyo.

of 4 and 7 feet, respectively. Pit 2 obliterated trench $B$ and penetrated to the base of the massive limestone.

Limestone bed $A$ forms a narrow outcrop band 50 to 100 feet wide at locality A-5. The bed is composed of light-gray dense to sandy limestone and contains irregular masses that are highly brecciated and silicified. The silification includes gray chert or chalcedony, brown chalcedony, and opal, apparently deposited in that sequence. Gray chert or chalcedony occurs in small blebs and irregular masses that replace limestone. Brown (and locally white) chalcedony is finely disseminated throughout the limestone and also locally fills tiny fractures in brecciated and recemented limestone. Opal occurs as colloform coatings in vugs and cavities in brecciated, but incompletely recemented, limestone, and locally forms small-scale stalactitelike pendants that hang from the upper surface of the vugs. Radiating crystal aggregates of bright-yellow uranophane as much as $0.5 \mathrm{~mm}$ in diameter locally dot the surface of opal in vugs (pl. 20A). Vug fillings of a pale-green dendritic mineral aggregate composed of calicite, opal, and a trace of uranophane are abundant (pl. 20B). The pale-green aggregates fluoresce bright yellow green in ultraviolet light in contrast to the discrete uranophane crystals, which do not fluoresce. A similar mineral aggregate of calcite, opal, and uranophane commonly occurs as a travertinelike coating as much as 5 to $10 \mathrm{~mm}$ thick on the underside of broken limestone fragments near the weathered surface of an outcrop. Though 
few of these travertinelike coatings have as noticeable a green tint as the vug occurrences, they fluoresce the same bright yellow green in ultraviolet light. Locally, joint surfaces in the silicified limestone are coated with a pale-green radioactive material that is probably similar in composition to the calcite, opal, and uranophane aggregates because the material fluoresces a similar color. Rarely, friable sandstone pellets as much as $10 \mathrm{~mm}$ across occur in the limestone and have a pale-green color that suggests the presence of uranophane.

The top foot of siliceous limestone at locality A-5 may contain as much as 7,500 cubic feet, or 625 tons of rock with an average uranium content of not more than 0.03 percent.

\section{LOCALITY 1}

Locality 1 occurs on a small point formed by limestone bed A where the outcrop varies from about 50 to 150 feet in width. Moderate to high radioactivity was detected within an area of about 4,800 square feet on the weathered surface of the limestone. Shallow trenches, designated $\mathrm{H}$ to $\mathrm{L}$, were opened up along the joints and fractures in the limestone, and pit 5 was excavated to a depth of $41 / 2$ feet in the limestone (fig. 14). The limestone

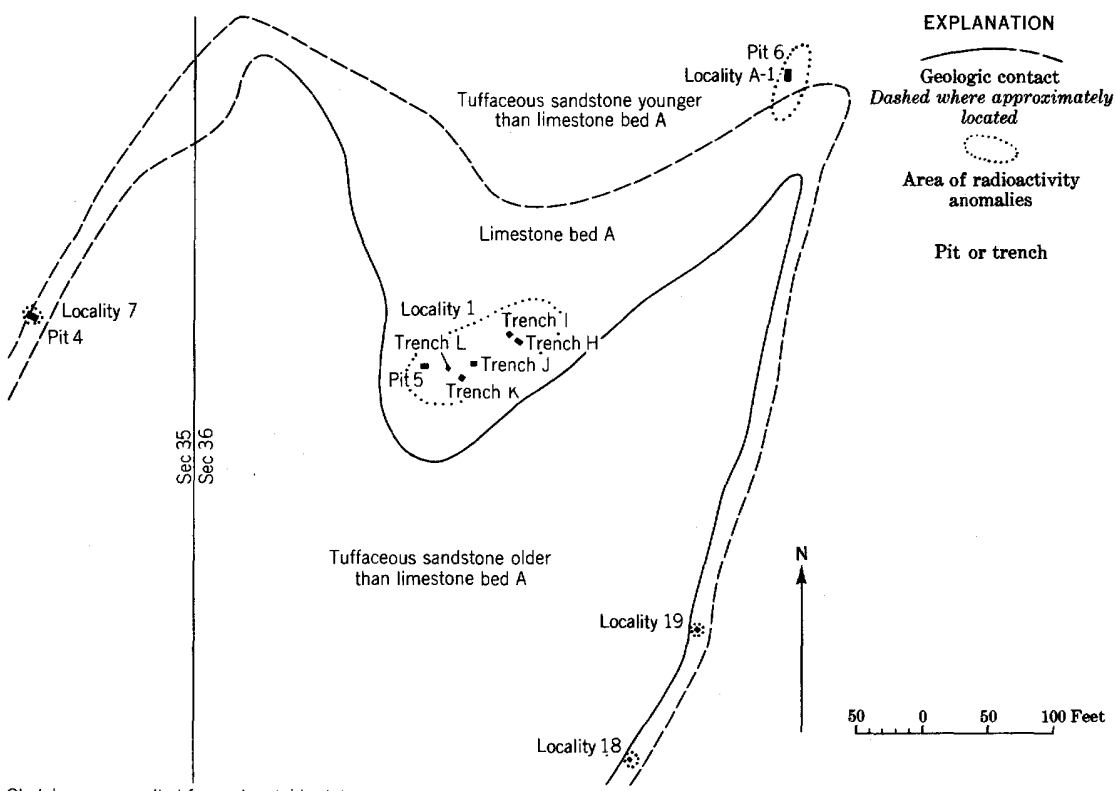

Sketch map compiled from planetable data

FIGURE 14.-Sketch map of locality 1 and adjacent areas showing location of radioactivity anomalies and pits from which samples were collected for analysis, T. 17 N., R. 88 W., Carbon County, Wyo. 
and the occurrence of the uranium is similar to that at locality A-5. In general, there is less gray chert, more minutely disseminated brown chalcedony, and fewer open vugs at locality 1 . Visible uranium minerals occur in the same variety of ways as at locality A-5.

A comparison of the analyses of samples from the shallow trenches along joints and from pit 5 (table 1) indicates that relatively intense mineralization is confined to the upper part of the limestone, particularly along the joints. A 12-inch channel sample from near a joint contained as much as 0.49 percent uranium, but the uranium content of limestone exposed in pit 5 ranged from 0.019 at the top to 0.009 at the bottom and had a weighted average of only 0.011 percent.

It is estimated that the top foot of siliceous limestone at locality 1 may contain as much as 4,800 cubic feet or 400 tons of rock with an average uranium content of not more than 0.02 percent.

\section{LOCALITY 1 A}

Locality $1 \mathrm{~A}$ is a small area of moderate to high radioactivity about 300 feet northeast of locality 1 (pl. 19 and fig. 14). The occurrence of uranium is very similar to locality 1 except that most of the visible uranium mineral occurs as pale-green fracture coatings. Abundant travertinelike coatings on limestone fragments are almost colorless but fluoresce bright yellow green. The uranium content of the limestone exposed in pit 6 , which was 41/2 feet deep, ranges from 0.020 to 0.008 percent and has a weighted average of only 0.011 .

Probably less than 50 tons of rock from locality $1 \mathrm{~A}$ contains as much as 0.02 percent uranium.

\section{LOCALITIES 6, 7, AND 16}

Localities 6, 7, and 16 lie within the narrow outcrop of limestone bed $\mathrm{A}$ that extends southeastward and southwestward from localities 1 and $1 \mathrm{~A} \mathrm{(pl.} 19$ and fig. 14). These three localities are all very small and each consists essentially of a few square feet of area where high radioactivity and visible uranium minerals were found. In each area the occurrence of uranium is very similar to the localities previously described. Pits 7, 4, and 8 were excavated to depths of 3 to $51 / 2$ feet, but the uranium minerals visible on the surface did not extend more than a few inches into the limestone and in each area the uranium content decreased rapidly with depth to an average of about 0.006 percent uranium at the bottom of the pits. 


\section{LOCALITY 9}

Locality 9 consists of several small areas of moderate radioactivity and one area of high radioactivity along a narrow partly covered ledge of limestone bed A (pl. 19). The limestone bed varies from dense to sandy limestone with small greenish sand pellets and contains irregular masses of dark-purplish-gray chert or chalcedony. No uranium minerals were identified.

\section{LOCALITY 17}

Locality 17 is unique in that moderate to high radioactivity is associated primarily with lenses of dark-purplish-gray chert and brown to white chalcedony that are up to several inches thick and several feet across. No uranium minerals were identified.

\section{LOCALTTY 11}

Locality 11 consists of a large triangular area of several acres near the center of sec. 25, T. 17 N., R. $88 \mathrm{~W}$., where the entire broad stripped surface of the limestone is weakly radioactive, and where there are several small spots of moderate radioactivity. Most of the points of moderate radioactivity are associated with irregular masses of dark-gray chert or chalcedony that stand up as knobby mounds 6 to 12 inches above the general surface of the limestone. Pit 3 was excavated to a depth of 6 feet to determine whether or not more intense mineralization might exist below the weathered surface of the limestone. The results showed strikingly little variation in the uranium content with depth below the surface. Such variations as were found seemed to be related more to the amount of chalcedony in the limestone than to any other single factor.

\section{POTENTIAL RESERVES}

No uranium deposits of sufficient size and grade to be considered profitable to mine were observed in the area investigated. Selected grab samples containing more than 0.1 percent uranium were collected from several places in the area, but these higher grade samples represent only small discontinuous mineralized areas.

Several small areas of siliceous limestone described in the preceding section contain on the order of several hundred tons of rock averaging about 0.02 to 0.03 percent uranium. In addition, there may be several hundred million tons of siliceous limestone, limestone, and calcareous sandstone containing an average of 0.005 to 0.01 percent uranium. Because of the lack of economic 
interest, the areal extent of this low-grade uraniferous rock was not determined.

\section{URANIUM CONTENT OF NATURAL WATER}

Thirty water samples were collected and submitted for uranium analysis (table 2). Most of the samples are from springs in the North Park(?) formation, though a few samples were collected from ponds or reservoirs. The analyses show a uranium content of from 1 to 14 parts per billion and an average of about 6. Analyses of samples from many springs throughout the Western United States indicate that the average uranium content is probably less than 0.5 parts per billion (P. F. Fix, written communication). Although the analyses of natural water from the Miller Hill area indicate that it is an uraniferous region, the low range of values makes it difficult to attempt to outline favorable areas for further exploration on the basis of water analyses.

\section{SPECTROGRAPHIC DATA}

Visual spectrographic analyses were obtained for 31 representative samples from the most highly mineralized parts of the limestone in the North Park(?) formation in the Miller Hill area. The samples include 3 channel samples from each of 8 pits, and 1 sample selected for its visible uranium minerals, from each of 7 localities near the pits. The reported values are shown in table 3 . Descriptions and locations of samples are given in table 1, plate 19 , and figures 12,13 , and 14 . Table 4 shows the range and calculated midpoint values of brackets on the standard spectrographic plates that correspond to the reported values in table 3 . Table 5 shows the elements looked for and the average limit of detection for each element. Less than one-third of the nearly 60 elements looked for were found in enough samples to be tabulated.

\section{ORIGIN OF URANIUM DEPOSITS}

Hypotheses that may be considered for the origin of uranium deposits in the Miller Hill area include hydrothermal deposition, concentration by living organisms, chemical concentration by evaporation of saline solutions, and concentration by redeposition of material leached from a disseminated source.

\section{HYDROTHERMAL DEPOSITION}

No evidence for hydrothermal activity other than the presence of uranium in Tertiary rocks and a small prospect for copper 
in the Precambrian rocks was observed in the Miller Hill area. Igneous rocks of Tertiary age are present 20 miles to the south and consist of basaltic flows, plugs, and dike on Battle Mountain and adjacent areas in the valley of the Little Snake River. Nevertheless, because hydrothermal solutions have been proposed as the origin of uranium in other districts far removed from any known source of hydrothermal or igneous activity, the fact that no source is evident need not eliminate consideration of this hypothesis. Generally, a hydrothermal deposit is recognized by its physical setting and the mineralogy of the deposit, but neither the age of the rocks, the distribution and shape of the occurrences, nor the relatively simple mineralogy of the uranium occurrences in the Miller Hill area provide unequivocal evidence in favor of ascending juvenile solutions. The preferential distribution of the uranium in the top of the limestone beds suggests the opposite of this hypothesis but is not conclusive.

\section{CONCENTRATION BY LIVING ORGANISMS}

During a preliminary study of the uranium occurrences in the Miller Hill area, Love noted the association of uranium with algal limestone. This observation led to the suggestion (Love, 1953, p. 9) that the uranium in the limestone may have been concentrated by the living organisms, whose calcareous remains were then incorporated into the limestone bed. He suggested that the lake water in which the algae lived might have become weakly uraniferous by the leaching of tuffaceous material that composes the bulk of the sedimentary deposit and that the organisms extracted the uranium from this water. Two additional mechanisms were then proposed: (a) deposition of silica and uranium from ground water to explain the association of uranium with chalcedony, and (b) fracture control of the deposition of chalcedony to explain the association of chalcedony with the uraniferous algal limestone, which is considered to be more brittle than the other strata. Presumably the association of microcrystalline uranophane with limestone would require further explanation.

\section{CHEMICAL CONCENTRATION BY EVAPORATION OF SALINE SOLUTIONS}

If the uraniferous limestone in the Miller Hill area were formed partly as a chemical precipitate, then consideration might be given to the possibility that uranium was concentrated by evap- 
oration of saline solutions. Evidence that this was an important mechanism for the concentration of uranium in limestone is insufficient. The hypothesis is inadequate, of course, to explain the occurrence of uranium in sandstone and quartzite.

\section{CONCENTRATION BY REDEPOSITION OF MATERIAL LEACHED FROM A DISSEMINATED SOURCE}

An epigenetic theory of origin of uranium deposits by leaching and reconcentration from tuffaceous rocks of Tertiary age has been suggested to explain several widely separated occurrences in the Rocky Mountain region. Investigation of uranium-bearing lignite in the western Dakota area in 1950 (Denson, Bachman, and Zeller, 1959) indicated the possibility of such a source for the uranium. Shortly thereafter, Love (1952) suggested a similar origin for the sandstone-type uranium deposits in the Pumpkin Buttes area, and similar hypotheses have been suggested for uranium-bearing sandstone deposits in the Slim Buttes area, Harding County, S. Dak. (Gill and Moore, 1955), in the White River badlands of South Dakota (Moore and Levish, 1955), and in the Poison basin area, Wyoming (Vine and Prichard, 1954). These last named areas all have the following features in common: (a) uranium occurs in or closely associated with tuffaceous rocks of Tertiary age; (b) the areas are in basins of thick, sedimentary deposits, remote from igneous activity; (c) uranium occurs chiefly in the form of secondary minerals. These features are also common to the Miller Hill occurrences. It seems desirable, therefore, to consider carefully this hypothesis for the origin of uranium and determine if it is also applicable here.

Uranium is one of many metallic elements in addition to the common rock-forming elements present in at least trace amounts in magma. It is generally thought that during the formation of plutonic igneous rocks uranium is normally concentrated in the residual liquor, from which it is deposited in pegmatites or veins (Rankama and Sahama, 1950, p. 634-635). When magma is extruded explosively and deposited as ash falls, uranium does not have an opportunity to crystallize out and consequently is disseminated throughout the volcanic rock, particularly in the glassy portion. Weathering and devitrification of the glassy material to form rock minerals would probably release uranium and other trace elements that are not required to enter into the crystalline structure of the minerals formed. Waters and Granger (1953, p. 20-22) have discussed the sequence of events that would 
take place following the devitrification of volcanic tuff. Included in this sequence of events is the release of excess silica and the resulting silicification of adjacent rocks.

Though the analytical data indicate no relation between the occurrence of uranium and of silicon, the field investigations show that at most places the dark-colored chert is somewhat uraniferous and that minutely disseminated chert or chalcedony is abundant in the vicinity of the higher grade uranium occurrences. A relation certainly exists between uranium and silica, though it may not be direct. Partial replacement of brecciated limestone by silica indicates that much of the silica is secondary. Stalactite-type deposits of chalcedony and opal in vugs indicate deposition of silica in air-filled spaces, presumably above the present water table and probably continuing up to the present time. The deposition of travertinelike aggregates of calcite, opal, and uranophane on the undersides of limestone fragments as well as in vugs indicates simultaneous transportation and deposition of calcium carbonate, silica, and uranium even up to the present time.

This evidence suggests a local source for the uranium, probably from sparse disseminations in the enclosing sediments. Limestone beds appear to have provided an environment which caused silica- and uranium-rich ground water to precipitate part of its dissolved solids. This process is not unique to this area. Goldschmidt (1954, p. 360) states: "It is well known that the presence of dissolved carbonate of lime reduces the solubility of silica in water." The greater concentration of uranium at the top of the limestone probably indicates that the principal direction of movement of the ground water was downward from the overlying sediments, then laterally along the upper surface of the limestone. This process of redistribution of uranium formerly disseminated throughout a large volume of rock and subsequent concentration in a chemically favorable zone probably accounts for concentrations of uranium of up to about 0.03 percent in limestone and chalcedony.

Concentrations of more than 0.03 percent uranium are confined to the top part of the limestone beds in areas where the overlying sediments have only recently been removed from the limestone. Where broad benches are formed on the stripped surface of limestone beds, uranium occurs chiefly in lenses and irregular masses of chert or chalcedony over most of the broad expanse of limestone, but local deposits with visible uranophane are located along a narrow margin where limestone has only 
recently been exposed to weathering. Pits dug back from the margin where the limestone has a thin cover of other rocks yielded no visible uranium minerals. This suggests that uranophane is being deposited only where limestone has recently been exposed to weathering. The travertinelike coatings of uranophane, calcite, and opal directly. below the exposed surface of limestone probably form by evaporation of capillary pore moisture, similar to the process by which caliche is formed. The fact that similar coatings are barren of uranium where found farther out on the limestone benches suggests that long exposure to the weather eventually causes the uranium to be leached, leaving only the calcite and opal.

Mobility of the uranium in the zone of weathering is further suggested by the disequilibrium of uranium and its radioactive decay products, particularly in channel samples. The values for radiometrically determined equivalent uranium are invariably higher than for uranium determined chemically in the topmost foot of limestone, while the lower part of the limestone more nearly approaches equilibrium. 
TABLE 1.-Analyses and descriptions of rock samples from the Miller Hill area

[Analyses by H. E. Bivens, R. F. Dufour, E. J. Fennelly, S. P. Furman, J. MeGurk, J. Meadows, W. Mountjoy, J. Patton, J. P. Schuch, J. L. Siverly, D. L. Stockwell, J. Wahlberg, and J. E. Wilson under supervision of F. L. Rader, Jr., U.S. Geological Survey]

\begin{tabular}{|c|c|c|c|c|c|c|c|c|c|}
\hline $\begin{array}{l}\text { Locality No., pit, or } \\
\text { trench (pl. 19, and } \\
\text { figs. } 12,13 \text {, and 14) }\end{array}$ & Location & Field No. & $\begin{array}{c}\text { Laboratory } \\
\text { No. }\end{array}$ & Type of sample ${ }^{1}$ & $\begin{array}{l}\text { Thickness } \\
\text { of sample } \\
\text { (inches) }\end{array}$ & $\begin{array}{c}\mathrm{eU} \\
\text { (percent) }\end{array}$ & $\underset{\text { (percent) }}{\mathbf{U}}$ & Rock type & $\begin{array}{l}\text { Stratigraphic } \\
\text { position }\end{array}$ \\
\hline$A-1$. & Sec. 34, T. 17 N., & VW3-203 & D92356 & Channel. . & 36 & 0.007 & 0.007 & Limestone. & Bed A. \\
\hline$A-2 \ldots$ & $\begin{array}{l}\text { R. } 88 \text { W. } \\
\text { Sec. } 35, T .17 \text { N., }\end{array}$ & $\begin{array}{r}204 \\
77\end{array}$ & $\begin{array}{l}\text { D92357 } \\
\text { D98773 }\end{array}$ & 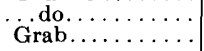 & 36 & $\begin{array}{l}.004 \\
.012\end{array}$ & .013 & Brown sandstone............. & $\begin{array}{l}\text { Do. } \\
20 \text { feet below }\end{array}$ \\
\hline & R. 88 W. & 78 & D99823 & ...do.. & & .004 & & Gray chert... & $\begin{array}{l}\text { top of bed } \mathrm{A} \text {. } \\
\text { Bed A. }\end{array}$ \\
\hline$A-3$. & $\begin{array}{l}\text { Sec. } 36, \text { T. } 17 \text { N., } \\
\quad \text { R. } 88 \text { W. }\end{array}$ & 41 & D94717 & ..do...... & $\ldots$ & .024 & .018 & $\begin{array}{l}\text { Limestone with . . . } \\
\text { dark-gray. } \\
\text { chalcedony. }\end{array}$ & Do. \\
\hline A-5 & Sec. $25, T, 17 \mathrm{~N}$ & 42 & D94718 & Channel........ & 192 & .007 & .006 & Limestone......... & Do. \\
\hline Pit 1: & R. $88 \mathrm{~W}$ W. & 12 & D925io & Composite grab. & & .006 & .008 & $\begin{array}{l}\text { Limestone witn } \\
\text { chalcedony. }\end{array}$ & Do. \\
\hline Northeast side. & & $\begin{array}{l}426 \\
427\end{array}$ & $\begin{array}{l}200099 \\
200100\end{array}$ & $\begin{array}{l}\text { Channel.......... } \\
\ldots \text { do........... }\end{array}$ & $\begin{array}{l}12 \\
12\end{array}$ & $\begin{array}{l}.003 \\
.012\end{array}$ & .009 & $\begin{array}{l}\text { Sandstone and soil... } \\
\text { Limestone with } \\
\text { chalcedony. }\end{array}$ & $\begin{array}{l}\text { Do. } \\
\text { Do. }\end{array}$ \\
\hline Southwest side. & & $\begin{array}{l}428 \\
429 \\
430 \\
431\end{array}$ & $\begin{array}{l}200101 \\
200102 \\
200103 \\
200104\end{array}$ & $\begin{array}{l}\ldots \text { do } \ldots \ldots \ldots \ldots \\
\text { Channel. } \ldots \ldots \ldots \\
\ldots \text { do. } \ldots \ldots \ldots \\
\end{array}$ & $\begin{array}{l}12 \\
18 \\
18 \\
12\end{array}$ & $\begin{array}{l}.012 \\
.010 \\
.004 \\
.014\end{array}$ & $\begin{array}{l}.012 \\
.012 \\
.012\end{array}$ & $\begin{array}{l}\ldots \text { do } \ldots \ldots \ldots \ldots \ldots \\
\text { Sandstone and soil.... } \\
\text { Limestone with }\end{array}$ & $\begin{array}{l}\text { Do. } \\
\text { Do. } \\
\text { Do. } \\
\text { Do. }\end{array}$ \\
\hline Pit $2 \ldots$ & & $\begin{array}{l}432 \\
433 \\
423\end{array}$ & $\begin{array}{l}200105 \\
200106 \\
200096\end{array}$ & Composite grab. & $\begin{array}{l}12 \\
12\end{array}$ & $\begin{array}{l}.008 \\
.006 \\
.018\end{array}$ & $\begin{array}{l}.003 \\
.004 \\
.029\end{array}$ & $\begin{array}{l}\text { do.................... } \\
\text { Limestone with } \\
\text { travertinelike } \\
\text { coatings. }\end{array}$ & $\begin{array}{l}\text { Do. } \\
\text { Do. } \\
\text { Do. }\end{array}$ \\
\hline & & 422 & 200095 & ...do. & & .052 & .042 & $\begin{array}{l}\text { Vuggy limestone with } \\
\text { uranophane. }\end{array}$ & Do. \\
\hline North side.... & & 416 & D99849 & Channel........ & 24 & .036 & .025 & $\begin{array}{l}\text { Limestone with } \\
\text { chalcedony. }\end{array}$ & Do. \\
\hline $\begin{array}{r}\text { East side..... } \\
\text { - } \\
\text { Trench A........ }\end{array}$ & & $\begin{array}{l}417 \\
418 \\
419 \\
420 \\
421 \\
434\end{array}$ & $\begin{array}{r}\text { D99850 } \\
200091 \\
200092 \\
200093 \\
200094 \\
200107\end{array}$ & 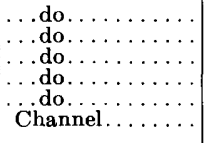 & $\begin{array}{l}24 \\
36 \\
24 \\
24 \\
36 \\
14\end{array}$ & $\begin{array}{l}.035 \\
.008 \\
.026 \\
.017 \\
.010 \\
.015\end{array}$ & $\begin{array}{l}.035 \\
.008 \\
.020 \\
.014 \\
.010 \\
.011\end{array}$ & 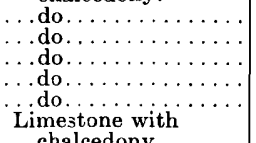 & $\begin{array}{l}\text { Do. } \\
\text { Do. } \\
\text { Do. } \\
\text { Do. } \\
\text { Do. } \\
\text { Do. }\end{array}$ \\
\hline & & 435 & 200108 & Composite grab.. & . & .13 & .10 & Limestone with & Do. \\
\hline Trench C... & & 13 & D92376 & Channel.... & 20 & .088 & .044 & $\begin{array}{l}\text { Limestone with } \\
\text { chalcedony. }\end{array}$ & Do. \\
\hline & & 21 & D92384 & Select grab. & $\cdots$ & .090 & .029 & .do........ & Do. \\
\hline
\end{tabular}


TABLE 1.-Analyses and descriptions of rock samples from the Miller Hill area-Continued

\begin{tabular}{|c|c|c|c|c|c|c|c|c|c|}
\hline $\begin{array}{l}\text { Locality No., pit, or } \\
\text { trench (pl. 19, and } \\
\text { figs. } 12,13, \text { and } 14)\end{array}$ & Location & Field No. & $\begin{array}{l}\text { Laboratory } \\
\text { No. }\end{array}$ & Type of sample 1 & $\begin{array}{l}\text { Thickness } \\
\text { of sample } \\
\text { (inches) }\end{array}$ & $\begin{array}{c}\mathrm{eU} \\
\text { (percent) }\end{array}$ & $\underset{\text { (percent) }}{\mathbf{U}}$ & Rock type & $\begin{array}{l}\text { Stratigraphic } \\
\text { position }\end{array}$ \\
\hline Trench D... & \multirow{14}{*}{$\begin{array}{l}\text { Sec. } 36, \text { T. } 17 \text { N., } \\
\text { R. } 88 \text { W. }\end{array}$} & 424 & 200097 & Composite grab. & & 0.065 & 0.053 & $\begin{array}{l}\text { Limestone with } \\
\text { uranophane on }\end{array}$ & Bed A. \\
\hline \multirow[t]{2}{*}{ Trench E........ } & & 436 & $2 \operatorname{co109}$ & Channel........ & 10 & .20 & .11 & Limestone with & Do. \\
\hline & & 72 & D97423 & Composite grab. & $\ldots$ & .39 & .39 & $\begin{array}{l}\text { uranophane. } \\
\text { Vuggy limestone }\end{array}$ & Do. \\
\hline Trench F........ & & 425 & $200 c 98$ & Channel.... & 12 & .042 & .038 & $\begin{array}{l}\text { with uranophane. } \\
\text { Limestone with } \\
\text { travertinelike } \\
\text { coatings and } \\
\text { uranophane }\end{array}$ & Do. \\
\hline Trench G......... & & $\begin{array}{l}437 \\
438\end{array}$ & $\begin{array}{l}200110 \\
200111\end{array}$ & $\begin{array}{l}\text { Channel......... } \\
\ldots \text { do........ }\end{array}$ & $\begin{array}{l}16 \\
10\end{array}$ & $\begin{array}{l}.064 \\
.042\end{array}$ & $\begin{array}{l}.060 \\
.030\end{array}$ & $\begin{array}{l}\text { uranophane. } \\
\text { Limestone........... }\end{array}$ & $\begin{array}{l}\text { Do. } \\
\text { Do. }\end{array}$ \\
\hline $1 \ldots \ldots \ldots \ldots \ldots$ & & 31 & D93543 & Composite grab & & .011 & .007 & Limestone with & Do. \\
\hline \multirow[t]{2}{*}{ Trench $\mathrm{H} \ldots \ldots$} & & $\begin{array}{l}32 \\
71\end{array}$ & $\begin{array}{l}\text { D93544 } \\
\text { D97423 }\end{array}$ & $\begin{array}{l}\text { Select grab...... } \\
\ldots \text { do.......... }\end{array}$ & & $\begin{array}{l}.37 \\
.39\end{array}$ & .27 & Limestone with & $\begin{array}{l}\text { Do. } \\
\text { Do. }\end{array}$ \\
\hline & & 451 & 200080 & Channel.... & 12 & .089 & .093 & $\begin{array}{l}\text { uranophane. } \\
\text { Limestone with }\end{array}$ & Do. \\
\hline Trench I.... & & 452 & 200081 & $\ldots$ do...... & 12 & .51 & .49 & $\begin{array}{l}\text { chalcedony. } \\
\text { Vuggy limestone }\end{array}$ & Do. \\
\hline Trench J. . & & 453 & 200082 & ...do.... & 12 & .022 & .021 & $\begin{array}{l}\text { with uranophane. } \\
\text { Limestone with }\end{array}$ & Do. \\
\hline \multirow[t]{2}{*}{$\begin{array}{l}\text { Trench } \mathbf{K} \ldots \ldots \ldots \\
\text { Trench } \mathbf{L} \ldots \ldots \ldots \ldots \\
\text { Pit } 5 \ldots \ldots \ldots \ldots \\
\end{array}$} & & $\begin{array}{r}454 \\
455 \\
70\end{array}$ & $\begin{array}{r}200083 \\
200084 \\
\text { D97429 }\end{array}$ & $\begin{array}{l}\ldots \text { do } \ldots \ldots \ldots \ldots \\
\text { Select grab. . . . } \ldots \\
\text { Select }\end{array}$ & $\begin{array}{r}12 \\
8\end{array}$ & $\begin{array}{l}.055 \\
.032 \\
.12\end{array}$ & $\begin{array}{l}.040 \\
.034 \\
.035\end{array}$ & $\begin{array}{l}\text { rhalcedony. } \\
\ldots \text { do } \ldots \ldots \ldots \ldots \ldots \ldots \\
\text { Limestone with }\end{array}$ & $\begin{array}{l}\text { Do. } \\
\text { Do. } \\
\text { Do. }\end{array}$ \\
\hline & & $\begin{array}{r}456 \\
457 \\
458 \\
30\end{array}$ & $\begin{array}{r}200085 \\
200086 \\
200087 \\
\text { D93542 }\end{array}$ & $\begin{array}{l}\text { Channel....... } \\
\ldots \text { do } \ldots \ldots \ldots \ldots \\
\ldots \text { do. } \ldots \ldots \ldots \ldots \\
\ldots \text { do } \ldots \ldots \ldots \ldots\end{array}$ & $\begin{array}{l}12 \\
12 \\
30 \\
48\end{array}$ & $\begin{array}{l}.038 \\
.015 \\
.006 \\
.012\end{array}$ & $\begin{array}{l}.019 \\
.009 \\
.009 \\
.007\end{array}$ & $\begin{array}{c}\text { chalcedony. } \\
\ldots \text { do } \ldots \ldots \ldots \ldots \\
\ldots \text { do } \ldots \ldots \ldots \ldots \\
\text { Limestone with }\end{array}$ & $\begin{array}{l}\text { Do. } \\
\text { Do. } \\
\text { Do. } \\
\text { Do. }\end{array}$ \\
\hline \multirow[t]{2}{*}{ Pit $6 \ldots \ldots \ldots \ldots$} & & 442 & 200071 & Select grab. & $\ldots \ldots$ & .12 & .11 & $\begin{array}{l}\text { chalcedony ledge. } \\
\text { Limestone with } \\
\text { chalcedony and }\end{array}$ & Do. \\
\hline & & 439 & 200068 & Channel... & 12 & .031 & .020 & $\begin{array}{l}\text { uranophane. } \\
\text { Limestone with }\end{array}$ & Do. \\
\hline & $\begin{array}{l}\text { Sec. } 25, \text { T. } 17 \text { N., } \\
\text { R. } 88 \text { W. }\end{array}$ & $\begin{array}{r}440 \\
441 \\
6\end{array}$ & $\begin{array}{r}200069 \\
200070 \\
D 92369\end{array}$ & $\begin{array}{l}\ldots \text { do. } \\
\ldots \text { do } . \\
\ldots \text { do } \ldots\end{array}$ & $\begin{array}{l}12 \\
30 \\
72\end{array}$ & $\begin{array}{l}.023 \\
.007 \\
.006\end{array}$ & $\begin{array}{l}.010 \\
.008 \\
.006\end{array}$ & 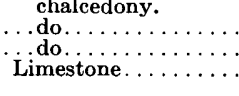 & $\begin{array}{l}\text { Do. } \\
\text { Do. } \\
\text { Do. }\end{array}$ \\
\hline
\end{tabular}




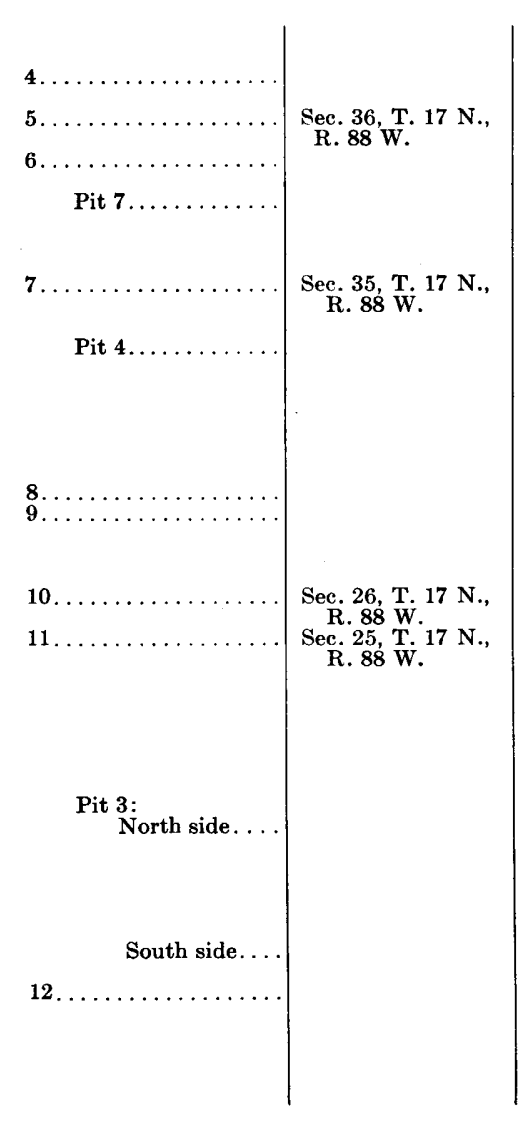

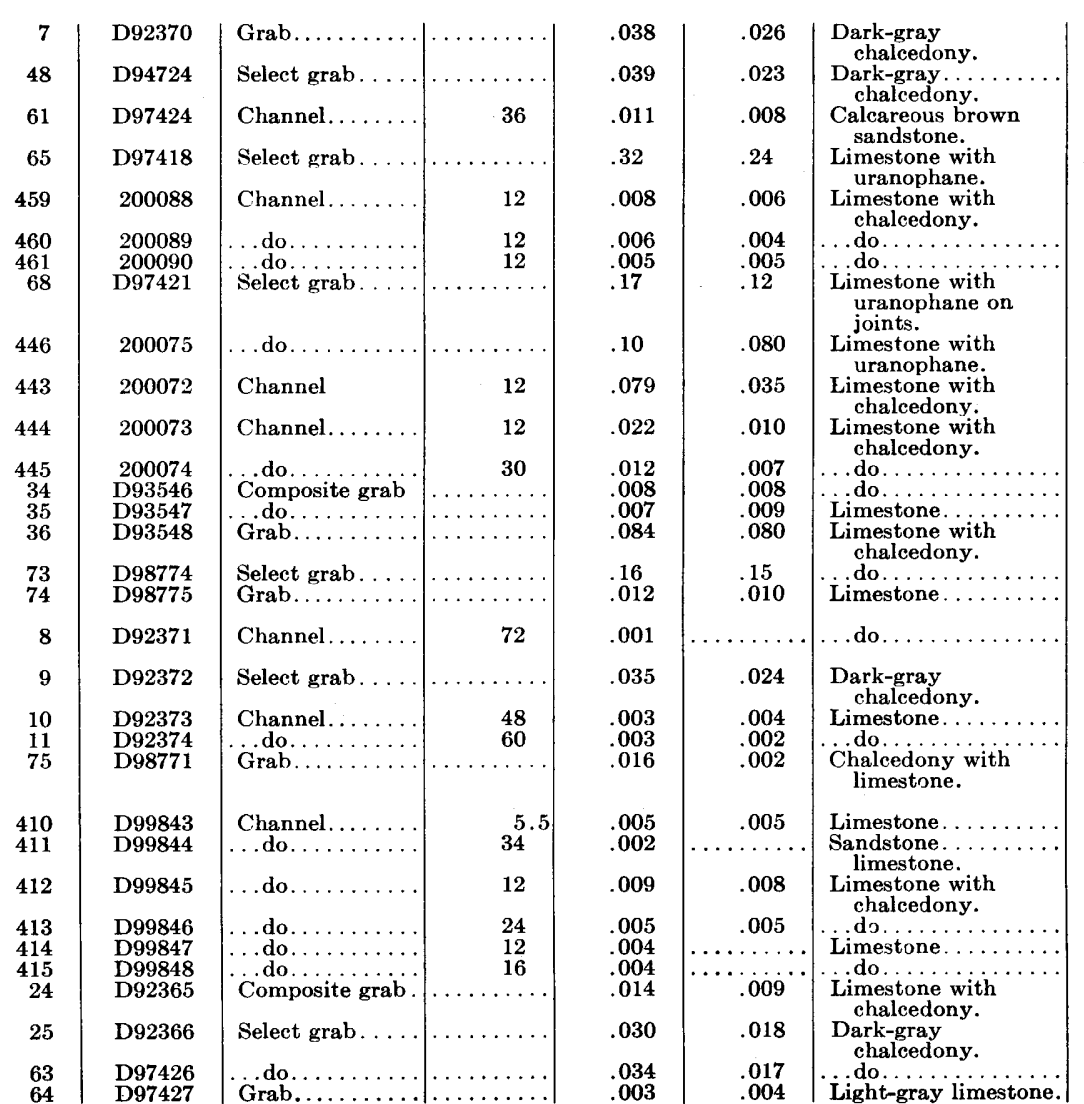

Do.

Do.

100 feet above

top of
Bed A.

Do.

Do.

Do.

Do.

Do.

Do.

Do.

Do.

Do.

Do.

Do.

Do

Do

Do.

Do.

Do.

Do.

Do.

Do.

Do.

Do. 
TABLE 1.-Analyses and descriptions of rock samples from the Miller Hill area-Continued

\begin{tabular}{|c|c|c|c|c|c|c|c|c|c|}
\hline $\begin{array}{l}\text { Locality No., pit, or } \\
\text { trench (pl. 19, and } \\
\text { figs. } 12,13 \text {, and 14) }\end{array}$ & Location & Field No. & $\begin{array}{c}\text { Laboratory } \\
\text { No. }\end{array}$ & Type of sample ${ }^{1}$ & $\begin{array}{l}\text { Thickness } \\
\text { of sample } \\
\text { (inches) }\end{array}$ & $\underset{\text { (percent) }}{\mathrm{eU}}$ & $\underset{\text { (percent) }}{\mathrm{U}}$ & Rock type & $\begin{array}{l}\text { Stratigraphic } \\
\text { position }\end{array}$ \\
\hline $14 \ldots$ & \multirow{2}{*}{$\begin{array}{l}\text { Sec. } 30, \text { T. } 17 \text { N., } \\
\text { R. } 87 \text { W. }\end{array}$} & 49 & D94725 & Composite grab. & . & 0.003 & . & Limestone with & Bed A \\
\hline 15. & & 62 & D97425 & Grab. & & .009 & 0.006 & $\begin{array}{l}\text { Limestone with } \\
\text { chalcedony and } \\
\text { travertinelike }\end{array}$ & Do. \\
\hline \multirow[t]{4}{*}{$16 \ldots \ldots \ldots \ldots \ldots$} & \multirow[t]{4}{*}{$\begin{array}{l}\text { Sec. } 36, \text { T. } 17 \text { N., } \\
\text { R. } 88 \text { W. }\end{array}$} & 43 & D94719 & Select grab..... & & .036 & .40 & $\begin{array}{l}\text { coatings. } \\
\text { Brown ehalcedony } \\
\text { with limestone }\end{array}$ & Do. \\
\hline & & 66 & D97419 & ...do. & & .25 & .22 & $\begin{array}{l}\text { Limestone with } \\
\text { brown chalcedony }\end{array}$ & Do. \\
\hline & & 447 & 200076 & Channel... & 12 & .050 & .035 & $\begin{array}{l}\text { and uranophane. } \\
\text { Limestone with }\end{array}$ & Do. \\
\hline & & $\begin{array}{l}448 \\
449 \\
450\end{array}$ & $\begin{array}{l}200077 \\
200078 \\
200079\end{array}$ & $\begin{array}{l}\ldots \text { do } \ldots \ldots \ldots \ldots \\
\ldots \text { do } \ldots \ldots \ldots \ldots \\
\ldots \text { do } \ldots \ldots \ldots \\
\ldots\end{array}$ & $\begin{array}{l}12 \\
40 \\
12\end{array}$ & $\begin{array}{l}.022 \\
.008 \\
.004\end{array}$ & $\begin{array}{l}.014 \\
.006\end{array}$ & $\begin{array}{l}\text { do } \ldots \ldots \ldots \ldots \ldots \ldots \\
\text { do do.......... } \\
\text { Calcareous }\end{array}$ & $\begin{array}{l}\text { Do. } \\
\text { Do. } \\
\text { Do. }\end{array}$ \\
\hline 17. & \multirow{3}{*}{$\begin{array}{l}\text { Sec. } 35, T .17 \text { N., } \\
\text { R. } 88 \text { W. } \\
\text { Sec. } 36, T \text {, } 17 \text { N., } \\
\text { R. } 88 \text { W. }\end{array}$} & 69 & D97428 & Select grab. & . & .11 & .065 & Dark-gray & Do. \\
\hline 18 & & 67 & D97420 & Select grab. & & .041 & .028 & $\begin{array}{l}\text { Limestone with } \\
\text { chalcedony and }\end{array}$ & Do. \\
\hline 19. & & 76 & D98772 & ...do. & & .042 & .015 & $\begin{array}{l}\text { uranophane (?) } \\
\text { Limestone with }\end{array}$ & Do. \\
\hline 21. & \multirow{4}{*}{$\begin{array}{l}\text { Sec. } 25, \text { T. } 17 \text { N., } \\
\text { R. } 88 \text { W. } \\
\text { Sec. } 30 \text {, T. } 17 \text { N., } \\
\text { R. } 87 \text { W. }\end{array}$} & 46 & D94722 & ...do. & & .039 & .027 & $\begin{array}{l}\text { chalcedony. } \\
\text { Gray chalcedony . . . }\end{array}$ & Do. \\
\hline \multirow[t]{3}{*}{22 . } & & 308 & D97436 & Channel... & 96 & .003 & .003 & $\begin{array}{l}\text { Limestone with } \\
\text { chalcedony. }\end{array}$ & Do. \\
\hline & & $\begin{array}{l}311 \\
312 \\
313\end{array}$ & $\begin{array}{l}\text { D97439 } \\
\text { D97440 } \\
\text { D97441 }\end{array}$ & $\begin{array}{l}\text {. do do. } \\
\ldots \text { do. } \\
\ldots \text { do } .\end{array}$ & $\begin{array}{l}72 \\
84 \\
60\end{array}$ & $\begin{array}{l}.016 \\
.005 \\
.010\end{array}$ & $\begin{array}{l}.008 \\
.006 \\
.005\end{array}$ & 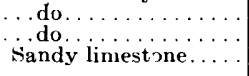 & $\begin{array}{l}\text { Do. } \\
\text { Do. } \\
30 \text { feet above }\end{array}$ \\
\hline & & 314 & D97442 & . . do. & 60 & .030 & .027 & . do. & 40 feet above \\
\hline \multirow[t]{3}{*}{$23 \ldots \ldots \ldots \ldots \ldots$} & \multirow{3}{*}{$\begin{array}{l}\text { Secs. } 30 \text { and } 31, \\
\text { T. } 17 \text { N., R. } 87 \text { W. }\end{array}$} & 309 & D97437 & Grab... & . & .018 & .009 & Limestone with & Bed B. \\
\hline & & $\begin{array}{l}310 \\
315\end{array}$ & $\begin{array}{l}\text { D97438 } \\
\text { D97443 }\end{array}$ & Composite grab. & & $\begin{array}{l}.019 \\
.008\end{array}$ & $\begin{array}{l}.009 \\
.007\end{array}$ & Calcareous sandstone. & $\begin{array}{l}\text { Do. } \\
15 \text { feet above }\end{array}$ \\
\hline & & 316 & D97444 & Composite grab. & & .014 & .013 & Sandy limestone. & $\begin{array}{l}55 \text { feet below } \\
\text { top of bed } B \text {. }\end{array}$ \\
\hline
\end{tabular}




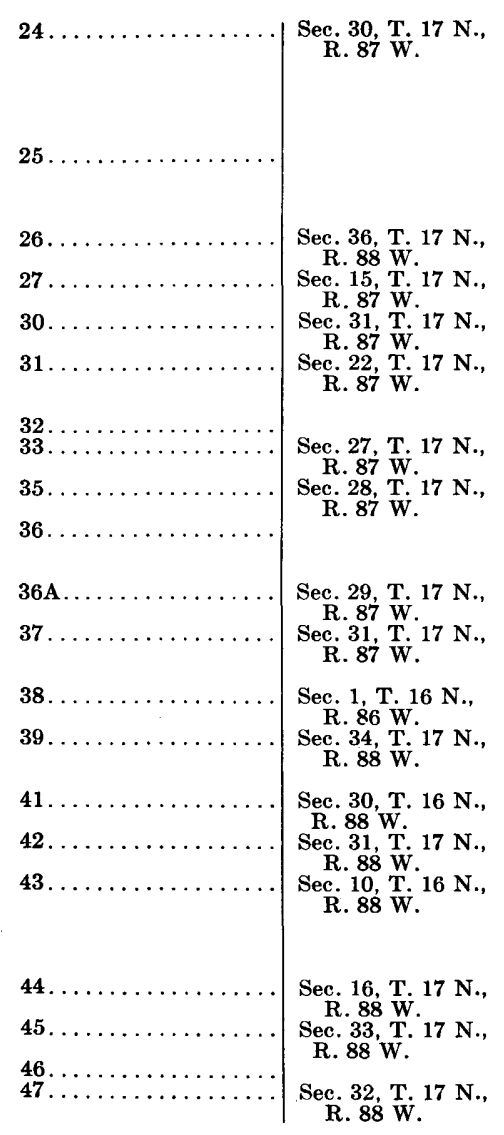

\begin{tabular}{|c|c|c|c|}
\hline 87 & D99829 & Grab... & . . \\
\hline 88 & D99830 & ..do.. & \\
\hline 306 & D97434 & Composite grab & \\
\hline $\begin{array}{l}305 \\
303\end{array}$ & $\begin{array}{l}\text { D97443 } \\
\text { D97431 }\end{array}$ & Grab...... & \\
\hline $\begin{array}{l}304 \\
317\end{array}$ & $\begin{array}{l}\text { D97432 } \\
\text { D97445 }\end{array}$ & $\begin{array}{c}\text { Composite grab } \\
\ldots \text { do }\end{array}$ & \\
\hline 52 & D96772 & ...do.. & \\
\hline 84 & D99826 & . .do.... & \\
\hline 86 & D99828 & Grab. . & \\
\hline $\begin{array}{l}235 \\
237 \\
242\end{array}$ & $\begin{array}{l}\text { D96785 } \\
\text { D96787 } \\
\text { D96790 }\end{array}$ & $\begin{array}{l}\ldots \text { do } \ldots \\
\ldots \text { do } \ldots \\
\ldots \text { do. } \ldots\end{array}$ & \\
\hline 244 & D96792 & $\ldots$ do...... & \\
\hline $\begin{array}{l}240 \\
241 \\
242 \\
243\end{array}$ & $\begin{array}{l}\text { D96788 } \\
\text { D96789 } \\
\text { D96790 } \\
D 96791\end{array}$ & $\begin{array}{l}\ldots \text { do } \ldots \ldots \ldots \\
\ldots \text { do } \ldots \ldots \ldots \\
\ldots \text { do } \ldots \ldots \ldots \ldots \\
\ldots \text { do } \ldots \ldots \ldots \\
\end{array}$ & \\
\hline 83 & D99825 & $\ldots$ do.... & \\
\hline $\begin{array}{l}236 \\
301\end{array}$ & $\begin{array}{l}\text { D96786 } \\
\text { D97430 }\end{array}$ & Composite grab & \\
\hline 202 & D92355 & Channel... & 36 \\
\hline $\begin{array}{r}79 \\
126\end{array}$ & $\begin{array}{l}\text { D99824 } \\
\text { D94727 }\end{array}$ & $\begin{array}{l}\text { Grab........ } \\
\text { Select grab. }\end{array}$ & \\
\hline 2 & D92368 & Grab... & \\
\hline 218 & D93565 & $\ldots$ do... & \\
\hline 219 & D93566 & . do... & \\
\hline 404 & D99842 & $\ldots$ do. . . . . & $\cdots$ \\
\hline 402 & D99840 & Channel..... & 12 \\
\hline $\begin{array}{r}403 \\
85\end{array}$ & $\begin{array}{l}\text { D99841 } \\
\text { D99827 }\end{array}$ & $\underset{\text { Grab. }}{\text { do } \ldots \ldots \ldots \ldots}$ & 12 \\
\hline
\end{tabular}

\begin{tabular}{l}
.017 \\
.022 \\
.020 \\
.004 \\
.021 \\
.003 \\
.013 \\
.012 \\
.013 \\
.013 \\
.016 \\
.009 \\
.013 \\
.011 \\
.012 \\
.013 \\
.015 \\
.017 \\
.006 \\
.006 \\
.008 \\
.019 \\
.006 \\
.007 \\
.007 \\
.009 \\
.018 \\
.017 \\
.015 \\
\hline
\end{tabular}

\begin{tabular}{|c|c|c|}
\hline .018 & Limestone with & \\
\hline .018 & $\begin{array}{l}\text { chalcedony. } \\
\text { Sandy limestone... }\end{array}$ & 15 feet above \\
\hline .009 & Chalcedony with & $\begin{array}{l}\text { top or bed B. } \\
\text { Bed B. }\end{array}$ \\
\hline $\begin{array}{l}.004 \\
.012\end{array}$ & $\begin{array}{l}\text { Limestone......... } \\
\text { Chalcedony..... }\end{array}$ & Bed A. \\
\hline $\begin{array}{l}.003 \\
.008\end{array}$ & $\begin{array}{l}\text { Calcareous sandstone. } \\
\text { Chalcedony .......... }\end{array}$ & $\begin{array}{l}\text { Bed A. } \\
\text { Bed B. }\end{array}$ \\
\hline .013 & Limestone..... & Bed A. \\
\hline .012 & Limestone with & Bed B(?). \\
\hline .011 & Limestone with & Do. \\
\hline $\begin{array}{l}.013 \\
.007\end{array}$ & $\begin{array}{l}\text { candy limestone...... } \\
\text { Calcareous sandstone. }\end{array}$ & $\begin{array}{l}\text { Do. } \\
\text { Do. }\end{array}$ \\
\hline & $\begin{array}{l}\text { Limestone with } \\
\text { chalcedony. }\end{array}$ & $\begin{array}{l}50 \text { feet below } \\
\text { top of bed B. }\end{array}$ \\
\hline .001 & Chalcedony...$\ldots \ldots$ & Bed B. \\
\hline $\begin{array}{l}.009 \\
.010\end{array}$ & $\begin{array}{l}\text { do. } \\
\text { do. }\end{array}$ & $\begin{array}{l}\text { Do. } \\
\text { Do. }\end{array}$ \\
\hline $\begin{array}{l}.009 \\
.013\end{array}$ & $\begin{array}{l}\text { Chert with limestone } \\
\text { Chert.............. }\end{array}$ & $\begin{array}{l}\text { Do. } \\
\text { Do. }\end{array}$ \\
\hline .009 & Gray chalcedony. & Do. \\
\hline $\begin{array}{l}.016 \\
.004\end{array}$ & Chalcedony & ? Do. \\
\hline .005 & Limestone. & Bed A. \\
\hline $\begin{array}{l}.007 \\
.012\end{array}$ & Brown chalcedony & $\begin{array}{l}\text { Do. } \\
\text { Bed C. }\end{array}$ \\
\hline .004 & $\ldots$ do............ & $?$ \\
\hline .007 & Limestone with & Bed $A(?)$ \\
\hline .007 & Sandy limestone. & $\begin{array}{l}10 \text { feet below } \\
\text { top of bed } \\
\text { A(?). }\end{array}$ \\
\hline .005 & Quartzite. & $\begin{array}{l}300 \text { feet below } \\
\text { top of bed A }\end{array}$ \\
\hline .019 & Sandy limestone..... & $\begin{array}{c}100 \text { feet below } \\
\text { top of bed A. }\end{array}$ \\
\hline $\begin{array}{l}.013 \\
.011\end{array}$ & Calcareous sandstone. & $\begin{array}{l}\text { Do. } \\
\text { Bed. B. }\end{array}$ \\
\hline
\end{tabular}


TABLE 1.-Analyses and descriptions of rock samples from the Miller Hill area-Continued

\begin{tabular}{|c|c|c|c|c|c|c|c|c|c|}
\hline $\begin{array}{l}\text { Locality No., pit, or } \\
\text { trench (pl. 19, and } \\
\text { figs. } 12,13, \text { and 14) }\end{array}$ & Location & Field No. & $\begin{array}{c}\text { Laboratcry } \\
\text { No. }\end{array}$ & Type of sample ${ }^{1}$ & $\begin{array}{l}\text { Thickness } \\
\text { of sample } \\
\text { (inches) }\end{array}$ & $\underset{\text { (percent) }}{\mathrm{eU}}$ & $\begin{array}{c}\mathrm{U} \\
\text { (percent) }\end{array}$ & Rock type & $\begin{array}{l}\text { Stratigraphic } \\
\text { position }\end{array}$ \\
\hline $51 \ldots$. & Sec. 16, T. 17 N., & 1 & D92367 & Channel...... & 12 & $<0.001$ & & Limestone. . & Bed A. \\
\hline 55. & $\begin{array}{l}\text { Sec. } 25, T, 17 \text { N., } \\
\text { R. } 88 \text { W. }\end{array}$ & 15 & D92378 & . do. & 60 & .006 & .006 & Limestone with & Do. \\
\hline $\begin{array}{l}56 \ldots \ldots \ldots \ldots \ldots \ldots \ldots \ldots \\
57 \ldots \ldots \ldots \ldots \ldots \ldots \ldots\end{array}$ & & $\begin{array}{l}16 \\
17\end{array}$ & $\begin{array}{l}\text { D92379 } \\
\text { D92380 }\end{array}$ & Grab......... & 60 & $\begin{array}{l}.005 \\
.015\end{array}$ & $\begin{array}{l}.004 \\
.013\end{array}$ & Chalcedony..... & $\begin{array}{l}\text { Do. } \\
\text { Do. }\end{array}$ \\
\hline $58 \ldots \ldots \ldots \ldots \ldots \ldots \ldots \ldots \ldots \ldots$ & $\begin{array}{l}\text { Sec. } 30, \text { T. } 17 \text { N., } \\
\text { R. } 87 \text { W. }\end{array}$ & 18 & D92381 & Channel. . & 60 & .004 & .002 & $\begin{array}{l}\text { Limestone with } \\
\text { chalcedony. }\end{array}$ & Do. \\
\hline 59 . & $\begin{array}{l}\text { Sec. } 30, \text { T. } 17 \text { N., } \\
\text { R. } 88 \text { W. }\end{array}$ & 19 & D92382 & ..do. & 12 & .002 & .001 & $\begin{array}{l}\text { Limestone with } \\
\text { chert. }\end{array}$ & Do. \\
\hline 60. & $\begin{array}{r}\text { Sec. } 30, \text { T. } 17 \text { N., } \\
\text { R. } 87 \text { W... }\end{array}$ & 20 & D92383 & ... do . & 60 & .004 & .002 & . .do......... & Do. \\
\hline 63. & $\begin{array}{l}\text { Sec. } 25, \text { T. } 17 \text { N., } \\
\text { R. } 88 \text { W. }\end{array}$ & 23 & D92364 & ...do. & 60 & .005 & .004 & ..do. . & Do. \\
\hline 66. & & 26 & D98781 & Grab. & $\ldots \ldots \ldots$ & .019 & .024 & $\begin{array}{l}\text { Limestone with } \\
\text { chert. }\end{array}$ & Bed A. \\
\hline $\begin{array}{l}67 \ldots \\
68 \ldots\end{array}$ & & $\begin{array}{l}27 \\
28\end{array}$ & $\begin{array}{l}\text { D93539 } \\
\text { D93540 }\end{array}$ & $\begin{array}{l}\text { Channel........ } \\
\ldots \text { do......... }\end{array}$ & $\begin{array}{l}24 \\
96\end{array}$ & $\begin{array}{l}.001 \\
.008\end{array}$ & .004 & $\begin{array}{l}\text { Limestone. . . } \\
\text { Limestone with } \\
\text { chert. }\end{array}$ & $\begin{array}{l}\text { Do. } \\
\text { Do. }\end{array}$ \\
\hline $69 \ldots$ & $\begin{array}{l}\text { Sec. 36, T. } 17 \text { N., } \\
\quad \text { R. } 88 \text { W. }\end{array}$ & 29 & D93541 & $\ldots$ do $\ldots . .$. & 60 & .005 & .004 & Limestone. . . . & Do. \\
\hline 73. & $\begin{array}{l}\text { Sec. } 35, \text { T. } 17 \text { N., } \\
\text { R. } 88 \text { W. }\end{array}$ & 33 & D93545 & ...do. & 72 & .007 & .007 & ..do. & Do. \\
\hline $77 \ldots$ & Sec. $26, T, 17$ N., & 37 & D93549 & Composite & . & .012 & .010 & ...do.. & Do. \\
\hline $78 \ldots \ldots \ldots \ldots \ldots \ldots \ldots \ldots \ldots$ & $\begin{array}{l}\text { Sec. } 36, \text { T. } 17 \text { N., } \\
\text { R. } 88 \text { W. }\end{array}$ & $\begin{array}{l}38 \\
39\end{array}$ & $\begin{array}{l}\text { D93550 } \\
\text { D93551 }\end{array}$ & Channel... & $\begin{array}{r}72 \\
120\end{array}$ & $\begin{array}{l}.007 \\
.002\end{array}$ & $\begin{array}{l}.007 \\
. .1 \%\end{array}$ & $\begin{array}{l}\ldots \text { do } \ldots \\
\ldots \text { do..... }\end{array}$ & $\begin{array}{l}\text { Do. } \\
\text { Do. }\end{array}$ \\
\hline 80 . & & 40 & D94716 & $\ldots$ do $\ldots \ldots \ldots \ldots$ & 72 & .005 & .005 & $\begin{array}{l}\text { Sandy limestone } \\
\text { with chalcedony. }\end{array}$ & Do. \\
\hline 84. & & 44 & D94720 & Channel....... & 48 & .006 & .006 & Limestone with & Do. \\
\hline 85. & $\begin{array}{l}\text { Sec. } 30, T ., 17 \text { N., } \\
\text { R. } 87 \text { W. }\end{array}$ & 45 & D94721 & $\ldots$ do $\ldots \ldots \ldots$ & 72 & .005 & .005 & Limestone & Do. \\
\hline 100. & $\begin{array}{l}\text { Sec. } 16, \mathrm{~T} .17 \text { N., } \\
\text { R. } 88 \mathrm{~W} .\end{array}$ & 100 & D92350 & Composite grab.. & . & .001 & & ...do. & Do. \\
\hline 102. & $\begin{array}{l}\text { Sec. } 17, \mathrm{~T} .17 \text { N., } \\
\text { R. } 88 \mathrm{~W} .\end{array}$ & 102 & D92351 & Channel. . & 84 & .001 & & ...do. . & Do. \\
\hline 105. & $\begin{array}{l}\text { Sec. } 30 \text {, T. } 17 \text { N., } \\
\text { R. } 88 \text { W. }\end{array}$ & 105 & D92353 & Grab.. & $\ldots$ & .001 & & ...do. & Bed A(?) \\
\hline 106. & $\begin{array}{l}\text { Sec. } 33, \text { T. } 17 \text { N., } \\
\text { R. } 88 \text { W. }\end{array}$ & 106 & D93552 & ...do... & 8 & .002 & & ...do... & $\begin{array}{l}50 \text { feet above } \\
\text { top of bed } A .\end{array}$ \\
\hline 107. & $\begin{array}{l}\text { Sec. } 8, T .16 \text { N., } \\
\text { R. } 88 \text { W. }\end{array}$ & 107 & D92354 & Channel. & 24 & .001 & & $\ldots$ do $\ldots$ & Bed A(?) \\
\hline
\end{tabular}




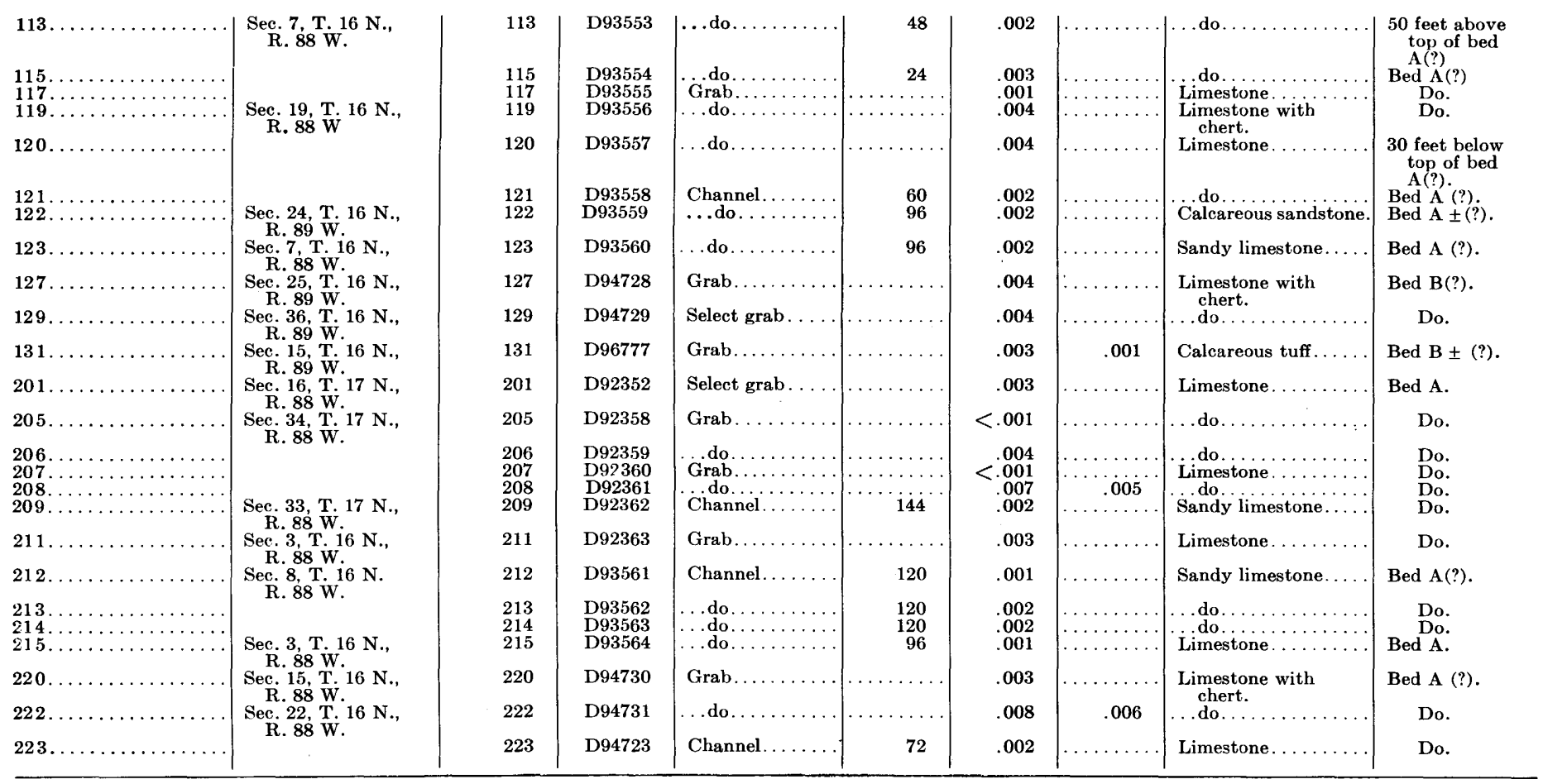

1 Channel samples from pits are listed in sequence from top to bottom. Select grab samples were taken from rock of highest uranium content. Composite grab samples, which were composed of chips, were collected over an area of outcrop. 
TABLE 2.-Analyses and descriptions of water samples from the Miller Hill area

[Chemical analyses by W. Mountjoy and J. P. Schuch, U.S. Geological Survey]

\begin{tabular}{|c|c|c|c|c|c|c|c|}
\hline \multirow{2}{*}{ Field No. } & \multirow{2}{*}{$\begin{array}{c}\text { Laboratory } \\
\text { No. }\end{array}$} & \multicolumn{3}{|c|}{ Location } & \multirow{2}{*}{$\begin{array}{l}\text { Type of } \\
\text { sample }\end{array}$} & \multirow{2}{*}{$\begin{array}{l}\text { Uranium } \\
\text { (parts per } \\
\text { billion) }\end{array}$} & \multirow{2}{*}{ Stratigraphic position } \\
\hline & & Sec. & T. & $\mathbf{R}$. & & & \\
\hline
\end{tabular}

North Park (?) formation

\begin{tabular}{|c|c|c|c|c|c|c|c|}
\hline $\begin{array}{r}\text { VW3-4 } \\
5 \\
22\end{array}$ & $\begin{array}{l}\text { D92386 } \\
\text { D92387 } \\
\text { D92388 }\end{array}$ & $\begin{array}{r}25 \\
25 \\
3\end{array}$ & $\begin{array}{l}17 \text { N. } \\
17 \text { N. } \\
16 \text { N. }\end{array}$ & $\begin{array}{l}88 \mathrm{~W} . \\
88 \mathrm{~W} . \\
88 \mathrm{~W} .\end{array}$ & $\begin{array}{l}\text { Pond...... } \\
\text { Spring..... }\end{array}$ & $\begin{array}{l}12 \\
10 \\
10\end{array}$ & $\begin{array}{l}\text { Basal conglomerate. } \\
\text { Do. } \\
\text { Between basal conglomerate }\end{array}$ \\
\hline $\begin{array}{r}60 \\
104\end{array}$ & $\begin{array}{l}\text { D96800 } \\
\text { D92389 }\end{array}$ & $\begin{array}{l}12 \\
18\end{array}$ & $18 \mathrm{~N}$. & $\begin{array}{l}89 \mathrm{~W} . \\
88 \mathrm{~W} \text {. }\end{array}$ & $\begin{array}{l}\text { Pond..... } \\
\text { Spring. . }\end{array}$ & $\begin{array}{l}1 \\
6\end{array}$ & $\begin{array}{l}\text { and limestone bed } \mathbf{A} \text {. } \\
\text { Basal conglomerate. } \\
\text { Between basal conglomerate }\end{array}$ \\
\hline $\begin{array}{l}108 \\
109 \\
110 \\
111 \\
112 \\
114 \\
116 \\
118 \\
124 \\
125 \\
128\end{array}$ & $\begin{array}{l}\text { D92390 } \\
\text { D92391 } \\
\text { D92392 } \\
\text { D93530 } \\
\text { D93531 } \\
\text { D93532 } \\
\text { D93533 } \\
\text { D93536 } \\
\text { D93537 } \\
\text { D93538 } \\
\text { D94710 }\end{array}$ & $\begin{array}{r}8 \\
7 \\
8 \\
6 \\
6 \\
8 \\
12 \\
18 \\
19 \\
8 \\
82 \\
32 \\
25\end{array}$ & $\begin{array}{l}16 \mathrm{~N} . \\
16 \mathrm{~N} . \\
16 \mathrm{~N} . \\
16 \mathrm{~N} . \\
16 \mathrm{~N} \text {. } \\
16 \mathrm{~N} \text {. } \\
16 \mathrm{~N} \text {. } \\
17 \mathrm{~N} \\
18 \mathrm{~N} \\
16 \mathrm{~N}\end{array}$ & $\begin{array}{l}88 \mathrm{~W} . \\
88 \mathrm{~W} . \\
88 \mathrm{~W} . \\
88 \mathrm{~W} . \\
88 \mathrm{~W} . \\
89 \mathrm{~W} . \\
88 \mathrm{~W} . \\
88 \mathrm{~W} . \\
88 \mathrm{~W} . \\
88 \mathrm{~W} . \\
89 \mathrm{~W} .\end{array}$ & 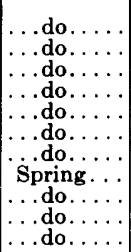 & $\begin{array}{r}5 \\
5 \\
8 \\
6 \\
5 \\
9 \\
6 \\
7 \\
8 \\
3 \\
14\end{array}$ & $\begin{array}{l}\text { and limestone bed A. } \\
\text { Do. } \\
\text { Do. } \\
\text { Do. } \\
\text { Do. } \\
\text { Do. } \\
\text { Do. } \\
\text { Do. } \\
\text { Do. } \\
\text { Basal conglomerate. } \\
\text { Do. } \\
\text { Between basal conglomerate }\end{array}$ \\
\hline $\begin{array}{l}130 \\
132 \\
210\end{array}$ & $\begin{array}{l}\text { D94711 } \\
\text { D96796 } \\
\text { D92394 }\end{array}$ & $\begin{array}{l}\mathbf{3 1} \\
\mathbf{3 2} \\
\mathbf{3 3}\end{array}$ & $\begin{array}{l}16 \mathrm{~N} . \\
18 \mathrm{~N} \\
17 \mathrm{~N}\end{array}$ & $\begin{array}{l}88 \mathrm{~W} \text {. } \\
88 \mathrm{~W} \text {. } \\
88 \mathrm{~W} \text {. }\end{array}$ & $\begin{array}{l}\text {.do..... } \\
\text { Pond.... } \\
\text { Spring. }\end{array}$ & $\begin{array}{r}8 \\
2 \\
13\end{array}$ & $\begin{array}{l}\text { and limestone bed } \mathrm{A} \text {. } \\
\text { Do. } \\
\text { Basal conglomerate. } \\
\text { Between basal conglomerate }\end{array}$ \\
\hline $\begin{array}{l}216 \\
217 \\
221 \\
224 \\
225 \\
226 \\
238 \\
239 \\
307\end{array}$ & $\begin{array}{l}\text { D93534 } \\
\text { D93535 } \\
\text { D94712 } \\
\text { D94713 } \\
\text { D94714 } \\
\text { D94715 } \\
\text { D96798 } \\
\text { D96799 } \\
\text { D97435 }\end{array}$ & $\begin{array}{r}15 \\
15 \\
15 \\
22 \\
22 \\
29 \\
28 \\
27 \\
7\end{array}$ & 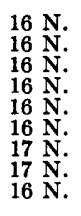 & $\begin{array}{l}88 \mathrm{~W} . \\
88 \mathrm{~W} \\
88 \mathrm{~W} \\
88 \mathrm{~W} \\
88 \mathrm{~W} . \\
88 \mathrm{~W} . \\
87 \mathrm{~W} . \\
87 \mathrm{~W} . \\
87 \mathrm{~W} .\end{array}$ & 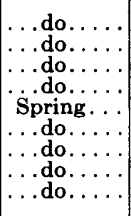 & $\begin{array}{l}4 \\
6 \\
5 \\
3 \\
2 \\
4 \\
5 \\
7 \\
6\end{array}$ & $\begin{array}{l}\text { Do. } \\
\text { Do. } \\
\text { Do. } \\
\text { Do. } \\
\text { Do. } \\
\text { Do. } \\
\text { Do. } \\
\text { Basal conglomerate. } \\
\text { Between limestone beds }\end{array}$ \\
\hline 318 & D98779 & 5 & $16 \mathrm{~N}$. & $87 \mathrm{~W}$. & $\ldots$ do... & 5 & $\begin{array}{l}\text { Between basal conglomerate } \\
\text { and limestone bed } \mathrm{A} \text {. }\end{array}$ \\
\hline \multicolumn{8}{|c|}{ Nugget sandstone } \\
\hline VW3-200 & D92393 & 27 & $17 \mathrm{~N}$. & $88 \mathrm{w}$. & Spring. . . & 4 & \\
\hline
\end{tabular}


TABLE 3.-Analyses, in percent, of $\$ 1$ mineralized limestone samples from the Miller Hill area ${ }^{1}$

[See table 4 for key to values used in this table. Visual spectrographic determinations by G. W. Boyes, N. M. Conklin, P. J. Dunton, and R. G. Havens, U.S. Geological Survey; chemical analyses for uranium by H. Bivens, R. Dufour, and J. Wahlberg, U.S. Geological Survey]

\begin{tabular}{|c|c|c|c|c|c|c|c|c|c|c|c|c|c|c|c|c|c|c|c|c|}
\hline \multirow{2}{*}{ Field No. } & \multirow{2}{*}{$\begin{array}{l}\text { Locality No. } \\
\text { (pl. 19 and } \\
\text { fig. 12) }\end{array}$} & \multicolumn{19}{|c|}{ Elements 23} \\
\hline & & $\mathrm{Si}$ & Al & $\mathrm{Fe}$ & $\mathrm{Ti}$ & Mn & $\mathrm{Ca}$ & $\mathbf{M g}$ & $\mathbf{N a}$ & $\mathbf{K}$ & $\mathrm{Ba}$ & $\mathrm{Cr}$ & $\mathbf{C u}$ & Mo & $\mathrm{Ni}$ & $\mathbf{P b}$ & $\mathrm{Sr}$ & v & $\mathrm{Zr}$ & $\mathbf{U}$ \\
\hline $\begin{array}{r}\text { VW3-452 } \\
43 \\
72 \\
65 \\
68 \\
442 \\
435 \\
443 \\
447 \\
419 \\
439 \\
456 \\
420 \\
448 \\
431 \\
421 \\
440 \\
444 \\
457 \\
458 \\
412 \\
441 \\
445 \\
449 \\
459 \\
410 \\
413 \\
\mathbf{4 6 1} \\
433 \\
460 \\
432\end{array}$ & $\begin{array}{r}1 \\
16 \\
A-5 \\
6 \\
7 \\
1 A \\
A-5 \\
7 \\
16 \\
A-5 \\
1 A \\
1 \\
A-5 \\
16 \\
A-5 \\
A-5 \\
1 A \\
7 \\
1 \\
1 \\
11 \\
1 A \\
7 \\
16 \\
6 \\
11 \\
11 \\
\text { A-5 } \\
6 \\
A-5\end{array}$ & 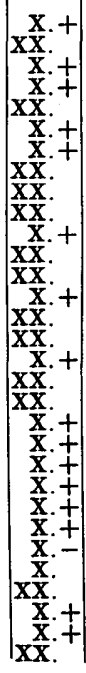 & 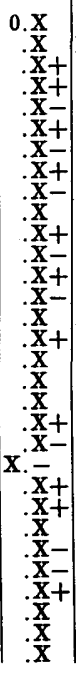 & 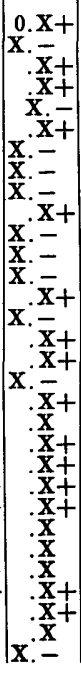 & $\begin{array}{l}0.0 \mathrm{X}- \\
.0 \mathrm{x}- \\
.0 \mathrm{x}- \\
.0 \mathrm{x} \\
.00 \mathrm{x}+ \\
.0 \mathrm{x}- \\
.00 \mathrm{x}+ \\
.0 \mathrm{x}- \\
.00 \mathrm{x}+ \\
.0 \mathrm{x}- \\
.0 \mathrm{x}- \\
.00 \mathrm{x}+ \\
.0 \mathrm{x}+ \\
.00 \mathrm{x}+ \\
.0 \mathrm{x}- \\
.0 \mathrm{x} \\
.0 \mathrm{x}- \\
.0 \mathrm{x}- \\
.0 \mathrm{x}- \\
.0 \mathrm{x} \\
.0 \mathrm{x}- \\
.0 \mathrm{x} \\
.0 \mathrm{x} \\
.0 \mathrm{x} \\
.0 \mathrm{x}- \\
.00 \mathrm{x}+ \\
.0 \mathrm{x}- \\
.0 \mathrm{x}- \\
.0 \mathrm{x}- \\
.0 \mathrm{x}- \\
.0 \mathrm{x}-\end{array}$ & $\begin{array}{l}0 . \mathrm{x}- \\
.0 \mathrm{x}+ \\
. \mathrm{x}- \\
. \mathrm{x} \\
.0 \mathrm{x}+ \\
. \mathrm{x}- \\
.0 \mathrm{x}+ \\
.0 \mathrm{x}+ \\
.0 \mathrm{x}+ \\
.0 \mathrm{x}+ \\
.0 \mathrm{x}+ \\
.0 \mathrm{x}+ \\
.0 \mathrm{x}+ \\
.0 \mathrm{x}+ \\
.0 \mathrm{x}+ \\
.0 \mathrm{x}+ \\
.0 \mathrm{x}+ \\
.0 \mathrm{x}+ \\
.0 \mathrm{x}+ \\
.0 \mathrm{x}+ \\
.0 \mathrm{x} \\
.0 \mathrm{x}+ \\
.0 \mathrm{x}+ \\
.0 \mathrm{x}+ \\
.0 \mathrm{x}+ \\
.0 \mathrm{x}+ \\
.0 \mathrm{x} \\
.0 \mathrm{x}+ \\
.0 \mathrm{x}+ \\
.0 \mathrm{x}+ \\
.0 \mathrm{x}+\end{array}$ & 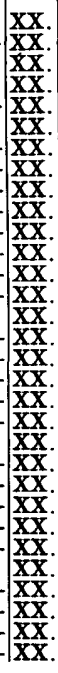 & 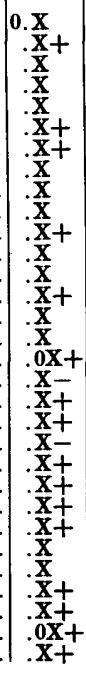 & 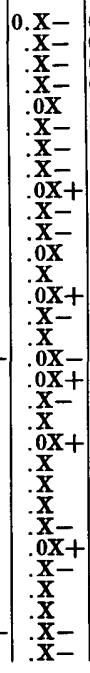 & 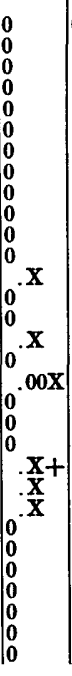 & $\begin{array}{l}0.0 \mathrm{x}+ \\
. \mathrm{x}- \\
.0 \mathrm{x}+ \\
.0 \mathrm{x}+ \\
.0 \mathrm{x} \\
.0 \mathrm{x}+ \\
.0 \mathrm{x}+ \\
. \mathrm{x}- \\
.0 \mathrm{x}+ \\
.0 \mathrm{x}+ \\
.0 \mathrm{x}+ \\
.0 \mathrm{x}- \\
.0 \mathrm{x}+ \\
.0 \mathrm{x}- \\
.0 \mathrm{x} \\
.0 \mathrm{x}+ \\
.0 \mathrm{x} \\
.00 \mathrm{x} \\
.0 \mathrm{x}- \\
.0 \mathrm{x}- \\
.0 \mathrm{x}- \\
.0 \mathrm{x}- \\
.0 \mathrm{x}- \\
.0 \mathrm{x}- \\
.0 \mathrm{x}- \\
.00 \mathrm{x}+ \\
.0 \mathrm{x}- \\
.0 \mathrm{x} \\
.00 \mathrm{x}+ \\
.0 \mathrm{x}- \\
.0 \mathrm{x}-\end{array}$ & $\begin{array}{l}0.00 \mathrm{x}- \\
.00 \mathrm{x}+ \\
.00 \mathrm{x}- \\
.00 \mathrm{x}- \\
.00 \mathrm{x}- \\
.00 \mathrm{x}- \\
.00 \mathrm{x} \\
.00 \mathrm{x} \\
.00 \mathrm{x} \\
.00 \mathrm{x} \\
.00 \mathrm{x} \\
.00 \mathrm{x} \\
.00 \mathrm{x} \\
.00 \mathrm{x} \\
.00 \mathrm{x} \\
.000 \mathrm{x}+ \\
.00 \mathrm{x}- \\
.00 \mathrm{x} \\
.00 \mathrm{x}- \\
.00 \mathrm{x}- \\
.00 \mathrm{x}- \\
.00 \mathrm{x}- \\
.00 \mathrm{x}- \\
.00 \mathrm{x}- \\
.00 \mathrm{x}- \\
.000 \mathrm{x}+ \\
.00 \mathrm{x}- \\
.00 \mathrm{x}- \\
.00 \mathrm{x}- \\
.00 \mathrm{x}- \\
.00 \mathrm{x}\end{array}$ & 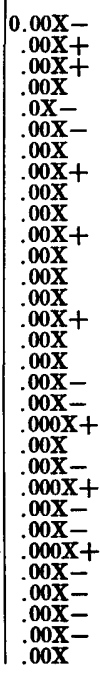 & 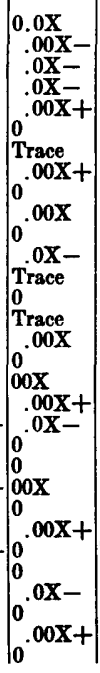 & 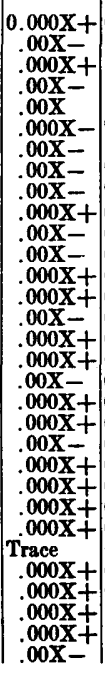 & $\begin{array}{l}0.00 \mathrm{X}- \\
.00 \mathrm{X}- \\
.00 \mathrm{X} \\
.0 \mathrm{X}- \\
.00 \mathrm{X} \\
\text { Trace } \\
.00 \mathrm{X} \\
\text { Trace } \\
\text { Trace } \\
0 \\
0 \\
0 \\
0 \\
0 \\
0 \\
0 \\
0 \\
0 \\
0 \\
0 \\
0 \\
0\end{array}$ & $\begin{array}{l}0.0 \mathrm{x} \\
.0 \mathrm{x}+ \\
.0 \mathrm{x} \\
.0 \mathrm{x}+ \\
.0 \mathrm{x}- \\
.0 \mathrm{x}+ \\
.0 \mathrm{x}+ \\
.0 \mathrm{x}- \\
.0 \mathrm{x} \\
.0 \mathrm{x} \\
.0 \mathrm{x}- \\
.0 \mathrm{x}- \\
.0 \mathrm{x} \\
.0 \mathrm{x} \\
.0 \mathrm{x} \\
.0 \mathrm{x} \\
.0 \mathrm{x}- \\
.0 \mathrm{x}- \\
.0 \mathrm{x} \\
.0 \mathrm{x}+ \\
.0 \mathrm{x}- \\
.0 \mathrm{x} \\
.0 \mathrm{x} \\
.0 \mathrm{x} \\
.0 \mathrm{x} \\
.0 \mathrm{x}+ \\
.0 \mathrm{x}- \\
.0 \mathrm{x} \\
.0 \mathrm{x}+ \\
.0 \mathrm{x} \\
.0 \mathrm{x}\end{array}$ & 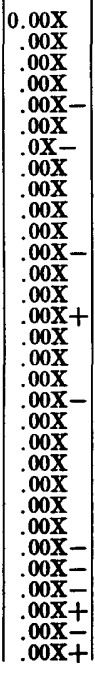 & 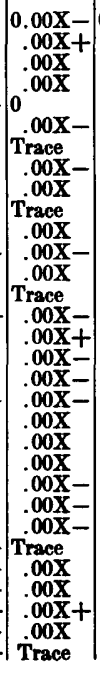 & \begin{tabular}{|l}
0.49 \\
.40 \\
.39 \\
.24 \\
.12 \\
.11 \\
.10 \\
.035 \\
.035 \\
.020 \\
.020 \\
.019 \\
.014 \\
.014 \\
.010 \\
.010 \\
.010 \\
.009 \\
.009 \\
.008 \\
.008 \\
.007 \\
.006 \\
.006 \\
.005 \\
.005 \\
.005 \\
.004 \\
.003
\end{tabular} \\
\hline
\end{tabular}

1 Uranium analyses are chemical determinations; all others are visual spectrographic analyses.

2 See table 4 for key to values for visual spectrographic data.

3 See table 5 for a list of the elements looked for and their limit of detection. 
TABLE 4.-Key to valuies for visual spectrographic data listed in table 3 , in percent

\begin{tabular}{|c|c|c|c|c|c|c|}
\hline Reported value & $\begin{array}{c}\text { Range of } \\
\text { stand }\end{array}$ & $\begin{array}{l}\text { f brackets on } \\
\text { dard plates }\end{array}$ & $\begin{array}{c}\text { Midpoint } \\
\text { of bracket } \\
\text { (calculated) }\end{array}$ & Reported value & $\begin{array}{c}\text { Range of brackets on } \\
\text { standard plates }\end{array}$ & $\begin{array}{l}\text { Midpoint } \\
\text { of bracket } \\
\text { (calculated) }\end{array}$ \\
\hline \multirow{2}{*}{$\begin{array}{l}\text { XX. } \\
\text { X. } \\
\text { X. } \\
\text { X. } \\
. \bar{X}+ \\
. X \\
. X- \\
.0 X+ \\
.0 X- \\
.0 X- \\
.00 X+\end{array}$} & \multirow{2}{*}{\multicolumn{2}{|c|}{$\begin{array}{ll} & \text { Over } 10 \\
.6 & -10 \\
.1 & -4.6 \\
.0 & -2.1 \\
.46 & -1.0 \\
.21 & - \\
.10 & -.46 \\
.046 & -.21 \\
.021 & -.10 \\
.010 & -.046 \\
.0046- & .021 \\
.0010\end{array}$}} & \multirow{2}{*}{\begin{tabular}{|c}
32 \\
6.8 \\
3.2 \\
1.5 \\
.68 \\
.32 \\
.15 \\
.068 \\
.032 \\
.015 \\
.0068
\end{tabular}} & $\begin{array}{l}0.00 \mathrm{X} \\
.00 \mathrm{X}- \\
.000 \mathrm{X}+ \\
.000 \mathrm{X}- \\
.000 \mathrm{X}-\end{array}$ & $\begin{array}{cc}0.0021- & 0.0046 \\
.0010- & .0021 \\
.00046- & .0010 \\
.00021- & .00046 \\
.00010- & .00021\end{array}$ & $\begin{array}{l}0.0032 \\
.0015 \\
.00068 \\
.00032 \\
.00015\end{array}$ \\
\hline & & & & $\begin{array}{l}\text { Trace. } \\
0 \ldots .\end{array}$ & \multicolumn{2}{|c|}{$\begin{array}{l}\text { Near threshold limit of } \\
\text { detection. } \\
\text { Less than threshold } \\
\text { limit of detection. }\end{array}$} \\
\hline
\end{tabular}

TABLE 5.-Approximate limit of detection, in percent, for the elements determined by the visual spectrographic method

[Revised May 22, 1952. Denver laboratory, U.S. Geological Survey]

\begin{tabular}{|c|c|c|c|c|c|}
\hline Element & $\begin{array}{l}\text { Approximate } \\
\text { limit of } \\
\text { detection }\end{array}$ & Element & $\begin{array}{l}\text { Approximate } \\
\text { limit of } \\
\text { detection }\end{array}$ & Element & $\begin{array}{c}\text { Approximate } \\
\text { limit of } \\
\text { detection }\end{array}$ \\
\hline $\begin{array}{l}\mathrm{Ag} \ldots \ldots \\
\mathrm{Al} \ldots \ldots \\
\mathrm{As} \ldots \ldots \\
\mathrm{Au} \ldots \ldots \\
\mathrm{B} \ldots \ldots \\
\mathrm{Ba} \ldots \ldots \\
\mathrm{Be} \ldots \ldots \\
\mathrm{Bi} \ldots \ldots \\
\mathrm{Ca} \ldots \ldots \\
\mathrm{Cd} \ldots \ldots \\
\mathrm{Ce} \ldots \ldots \\
\mathrm{Co} \ldots \ldots \\
\mathrm{Cr} \ldots \ldots \\
\mathrm{Cs} \ldots \ldots \\
\mathrm{Cu} \ldots \ldots \\
\mathrm{Fe} \ldots \ldots \\
\mathrm{Ga} \ldots \ldots \\
\mathrm{Gd} \ldots \ldots \\
\mathrm{Ge} \ldots \ldots\end{array}$ & $\begin{array}{l}0.0001 \\
.001 \\
.1 \\
.005 \\
.005 \\
.0001 \\
.0001 \\
.001 \\
.001 \\
.005 \\
.05 \\
.0005 \\
.0005 \\
1.0 \\
.0001 \\
.001 \\
.001 \\
.05 \\
.0005\end{array}$ & $\begin{array}{l}\mathrm{Hf} \ldots \ldots \\
\mathrm{Hg} \ldots \ldots \\
\mathrm{In} \ldots \ldots \\
\mathrm{Ir} \ldots \ldots \\
\mathrm{K} \ldots \ldots \\
\mathrm{La} \ldots \ldots \\
\mathrm{Li} \ldots \ldots \\
\mathrm{Mg} \ldots \\
\mathrm{Mo} \ldots \\
\mathrm{Mn} \ldots \\
\mathrm{Na} \ldots \\
\mathrm{Nb} \ldots \\
\mathrm{Nd} \ldots \\
\mathrm{Ni} \ldots \\
\mathrm{Os} \ldots \ldots \\
\mathrm{P} \ldots \ldots \\
\mathrm{Pb} \ldots \ldots \\
\mathrm{Pd} \ldots \ldots \\
\operatorname{Pr} \ldots \ldots\end{array}$ & $\begin{array}{l}0.1 \\
1.0 \\
.001 \\
.005 \\
1.0 \\
.005 \\
.01 \\
.005 \\
.001 \\
.0005 \\
.05 \\
.005 \\
.01 \\
.0005 \\
.005 \\
.5 \\
.001 \\
.0005 \\
.005\end{array}$ & 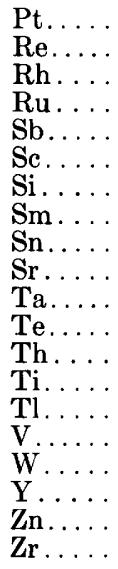 & $\begin{array}{l}0.005 \\
.005 \\
.005 \\
.005 \\
.05 \\
.001 \\
.001 \\
.01 \\
.001 \\
.0005 \\
.05 \\
.5 \\
.05 \\
.001 \\
.05 \\
.0001 \\
.01 \\
.001 \\
.05 \\
.001\end{array}$ \\
\hline
\end{tabular}




\section{REFERENCES CITED}

Ball, M. W., and Stebinger, Eugene, 1910, The eastern part of the Little Snake River coal field, Wyoming: U.S. Geol. Survey Bull. 381-B, p. 186-213.

Bradley, W. H., 1945, Geology of the Washakie Basin, Sweetwater and Carbon Counties, Wyoming, and Moffat County, Colorado: U.S. Geol. Survey Oil and Gas Inv. Prelim. Map 32.

Campbell, M. R., and others, 1925, Geologic map of Wyoming: U.S. Geol. Survey, Geologic Atlas of the United States, State of Wyoming, scale, $1: 500,000$.

Denson, N. M., Bachman, G. O., and Zeller, H. D., 1959, Uranium-bearing lignite in northwestern South Dakota and adjacent States; U.S. Geol. Survey Bull. 1055-B.

Gill, J. R., and Moore, G. W., 1955, Carnotite-bearing sandstone in Cedar Canyon, Slim Buttes, Harding County, South Dakota: U.S. Geol. Survey Bull. 1009-I, p. 249-264.

Goldschmidt, V. M. (edited by Alex Muir), 1954, Geochemistry: Oxford, Clarendon Press, 730 p.

Hague, Arnold, and Emmons, S. F., 1877, Descriptive geology: U.S. Geol. Explor. 40th Parallel (King), v. 2.

Henderson, J. R., 1954, Airborne radioactivity survey of parts of Savery NE and NW quadrangles, Carbon County, Wyoming: U.S. Geol. Survey TEM-747, open-file report.

King, Clarence, 1876, Annual report upon the geological exploration of the fortieth parallel from the Sierra Nevada to the eastern slope of the Rocky Mountains: Washington, U.S. Government Printing Office, map 1 of atlas.

Love, J. D., 1952, Preliminary report on uranium deposits in the Pumpkin Buttes area, Powder River Basin, Wyoming: U.S. Geol. Survey Circ. 176, 37 p.

1953, Preliminary report on the uranium deposits in the Miller Hill area, Carbon County, Wyoming: U.S. Geol. Survey Circ. 278, 10 p.

Love, J. D., Weitz, J. L., and Hose, R. K., 1955, Geologic map of Wyoming: U.S. Geol. Survey map, scale, 1:500,000.

McGrew, P. O., 1951, Tertiary stratigraphy and paleontology of south-central Wyoming: Wyoming Geol. Assoc. Guidebook 6th Ann. Field Conf., p. 54-57.

1953, Tertiary deposits of southeastern Wyoming: Wyoming Geol. Assoc. Guidebook 8th Ann. Field Conf., p. 61-64.

McKee, E. D., and Weir, G. W., 1953, Terminology for stratification and cross-stratification in sedimentary rocks: Geol. Soc. America Bull., v. 64, p. $380-390$.

Meuschke, J. L., and Moxham, R. M., 1953, Airborne radioactivity survey of the Miller Hill area, Carbon County, Wyoming: U.S. Geol. Survey TEM-606, open-file report.

Moore, G. W., and Levish, Murray, 1955, Uranium-bearing sandstone in the White River badlands, Pennington County, South Dakota: U.S. Geol. Survey Circ. 359, 7 p.

Rankama, Kalervo, and Sahama, T. G., 1950, Geochemistry: Chicago, Univ. of Chicago press. 
Stephens, J. G., and Bergin, M. J., 1959, Reconnaissance investigation of uranium occurrences in the Sartaoga area, Carbon County, Wyoming: U.S. Geol. Survey Bull. 1046-M, p. 321-338.

Veatch, A. C., 1907, Coal fields of east-central Carbon County, Wyoming: U.S. Geol. Survey Bull. 316-D, p. 244-260.

Vine, J. D., and Prichard, G. E., 1954, Uranium in the Poison Basin area, Carbon County, Wyoming: U.S. Geol. Survey Circ. 344, 8 p.

Waters, A. C., and Granger, H. C., 1953, Volcanic debris in uraniferous sandstones, and its possible bearing on the origin and precipitation of uranium: U.S. Geol. Survey Circ. 224, 26 p.

Wood, H. E., and others, 1941, Nomenclature and correlation of the North American continental Tertiary: Geol. Soc. America Bull., v. 52, p. 1-48. 


\section{INDEX}

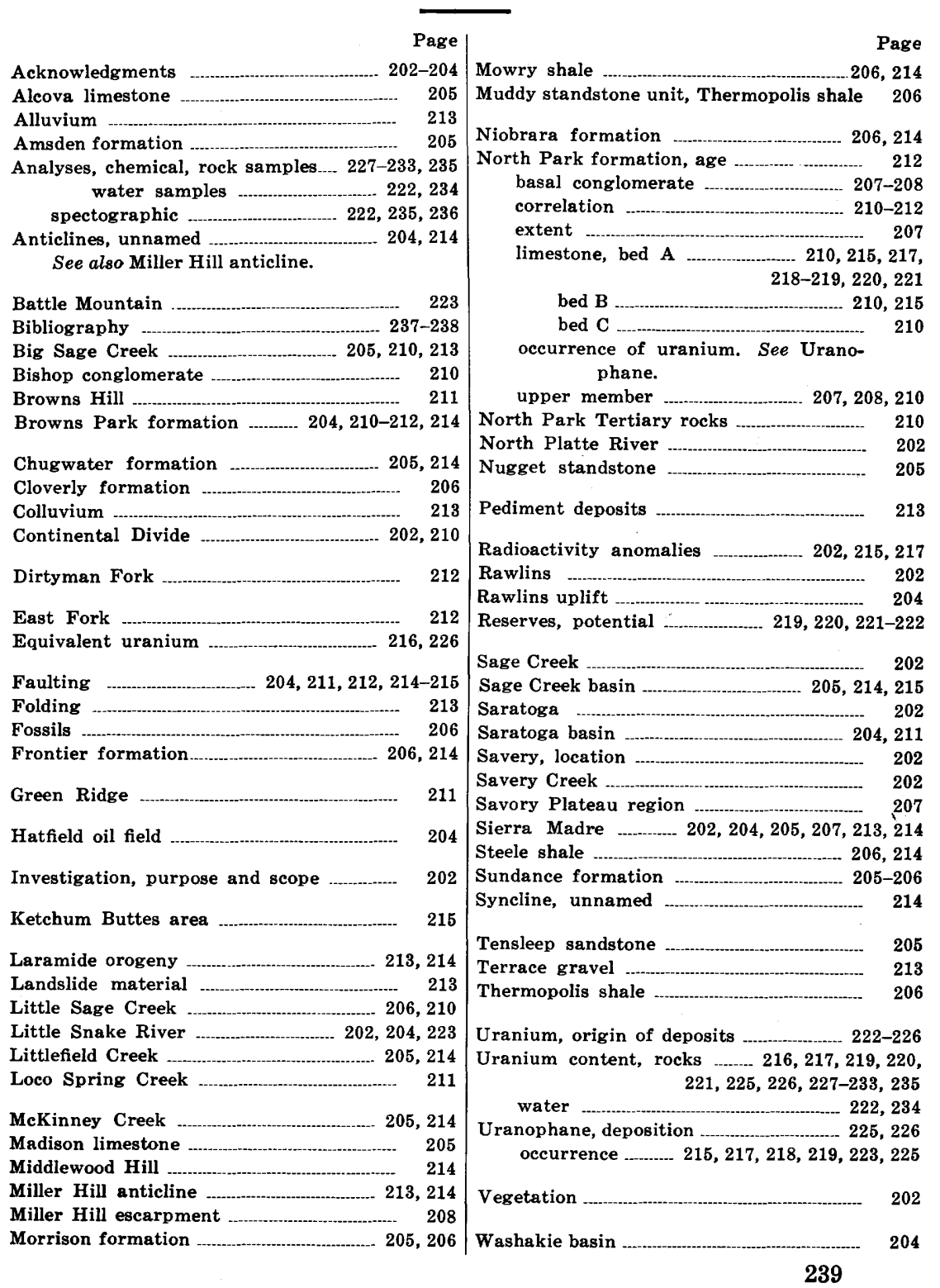




